University of Rhode Island

DigitalCommons@URI

Open Access Master's Theses

1979

\title{
ECONOMIC DEVELOPMENT IN RHODE ISLAND POLICIES AND STRATEGIES
}

David R. Westcott

University of Rhode Island

Follow this and additional works at: https://digitalcommons.uri.edu/theses

\section{Recommended Citation}

Westcott, David R., "ECONOMIC DEVELOPMENT IN RHODE ISLAND POLICIES AND STRATEGIES" (1979). Open Access Master's Theses. Paper 395.

https://digitalcommons.uri.edu/theses/395

This Thesis is brought to you for free and open access by DigitalCommons@URI. It has been accepted for inclusion in Open Access Master's Theses by an authorized administrator of DigitalCommons@URI. For more information, please contact digitalcommons-group@uri.edu. 


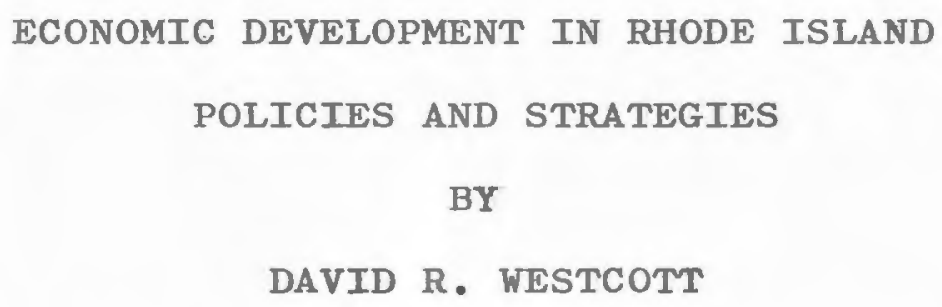

A THESIS PROJECT SUBMITTED IN PARTIAL FULFILLMENT OF THE REQUIREMENTS FOR THE DEGREE OF MASTER OF COMMUNITY PLANNING 


\section{MASTER OF COMMUNITY PLANNING}

THESIS PROJECT

OF

DAVID R. WESTCOTT

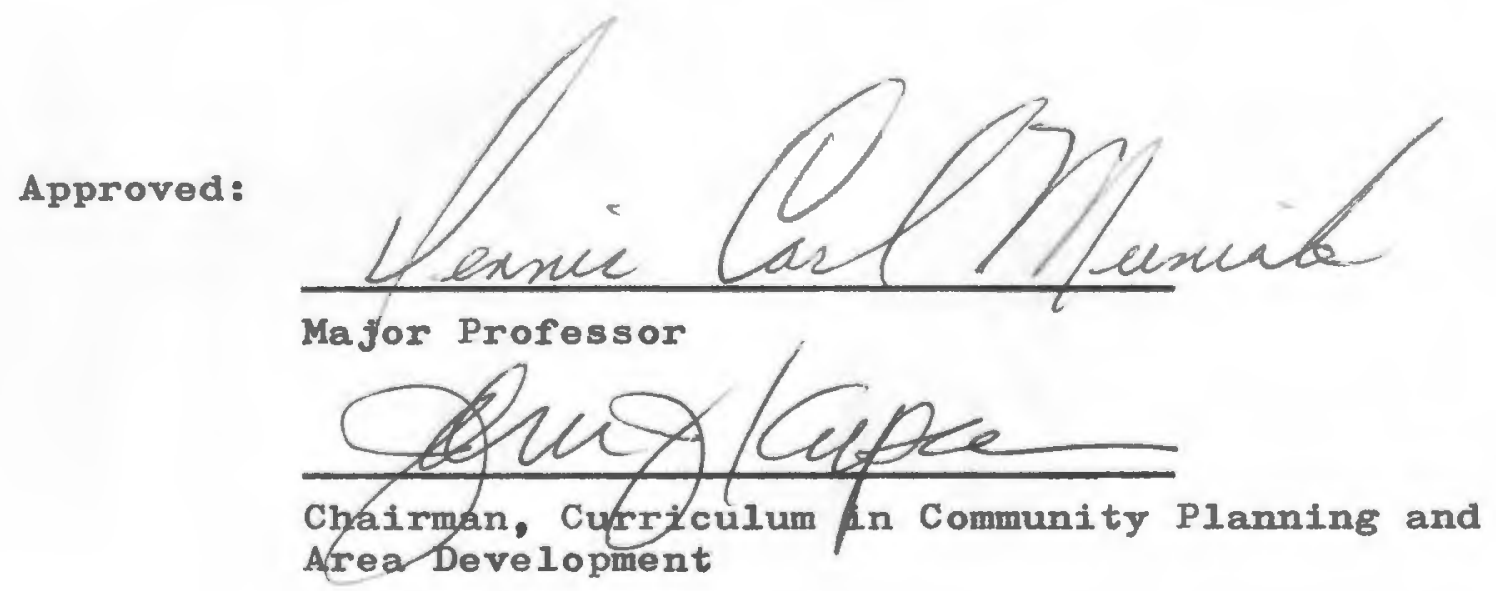

UNIVERSITY OF RHODE ISLAND

1979 


\section{ACKNOWLEDGEMENTS}

I would like to thank President Frank Newman of the University of Rhode Island who was instrumental in my involvement with economic development in Rhode Island.

I would also like to thank my advisor, Dr. Dennis C. Muniak, for services rendered and my wife, Iris $K$. Westcott for her infinite patience. 


\begin{abstract}
This project consists of a brief history of the Rhode Island economy, a discussion of the need for economic development, and some of the advantages and disadvantages of development. It also discusses Rhode Island's assets, resources, and limiting factors to economic development, leading to recommendations of policy priorities and strategies for action to improve Rhode Island's economy.
\end{abstract}




\section{TABLE OF COYTENTS}

$$
\text { page }
$$

I. INTRODUCTION

1.

II. BICKGROINND

3.

HISTORY

3.

TIE NEH FOR ECONOAIC DEVIAOMENT

8.

III. ADVANTAGES AND DISADVANTIGES OF DEVELOMNENT

16.

ADVANTAGES

16.

DISAUVANTAGES

18

IV. RHODE ISLAND'S ASSITS

20.

NATURAL, RESOURCHS

20.

COASTAL, ZOSE

20.

FRISII WATER RESOURCLS

23.

LAND

27 .

OTHER NATURAL RESOURCLS

28.

QUALITY OF LIFE

30.

ECONONIC AUVANTAGES

32.

PROXIMITY TO MARKETS

32.

SMALL FIRN SIZE

33.

LABOR

33.

TAXES

34.

AVALABILITY OF CAPITAL

35. 
GOVIRRNIENT ASSLTS 35.

GUVLRNOR 35 .

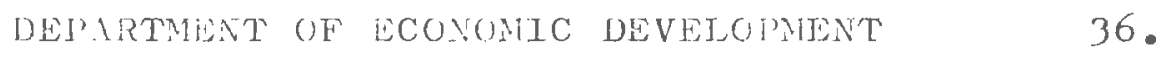

ST ITEWTUE :I. INING PROGRAM 37.

OTHER AR, ENCIES 38.

SUMMARY, SECTTON IV 38 •

V. KLY INDUSTRJISS 41.

JEWELRY AND SILV:SRWRE 41 .

SHIPBUILDING 42 .

FISUING 42.

LVERGY, 'RODLCTION 43.

SIITIIING 44.

TOURISM 45.

OTHTR INUUSTRIES 46.

VI. LIMITING FACTORS 49.

SHORTAGH: OF I\DUSTRIMI SITLS 49.

INFRASTRUCTURE 51 .

TRANSPORTATION 52 •

Roads and Bridges 52 .

Railroads 55.

Air Service 58.

Bay Shipping 60.

haTtR StiPLILS 61.

SEWERS 62. 


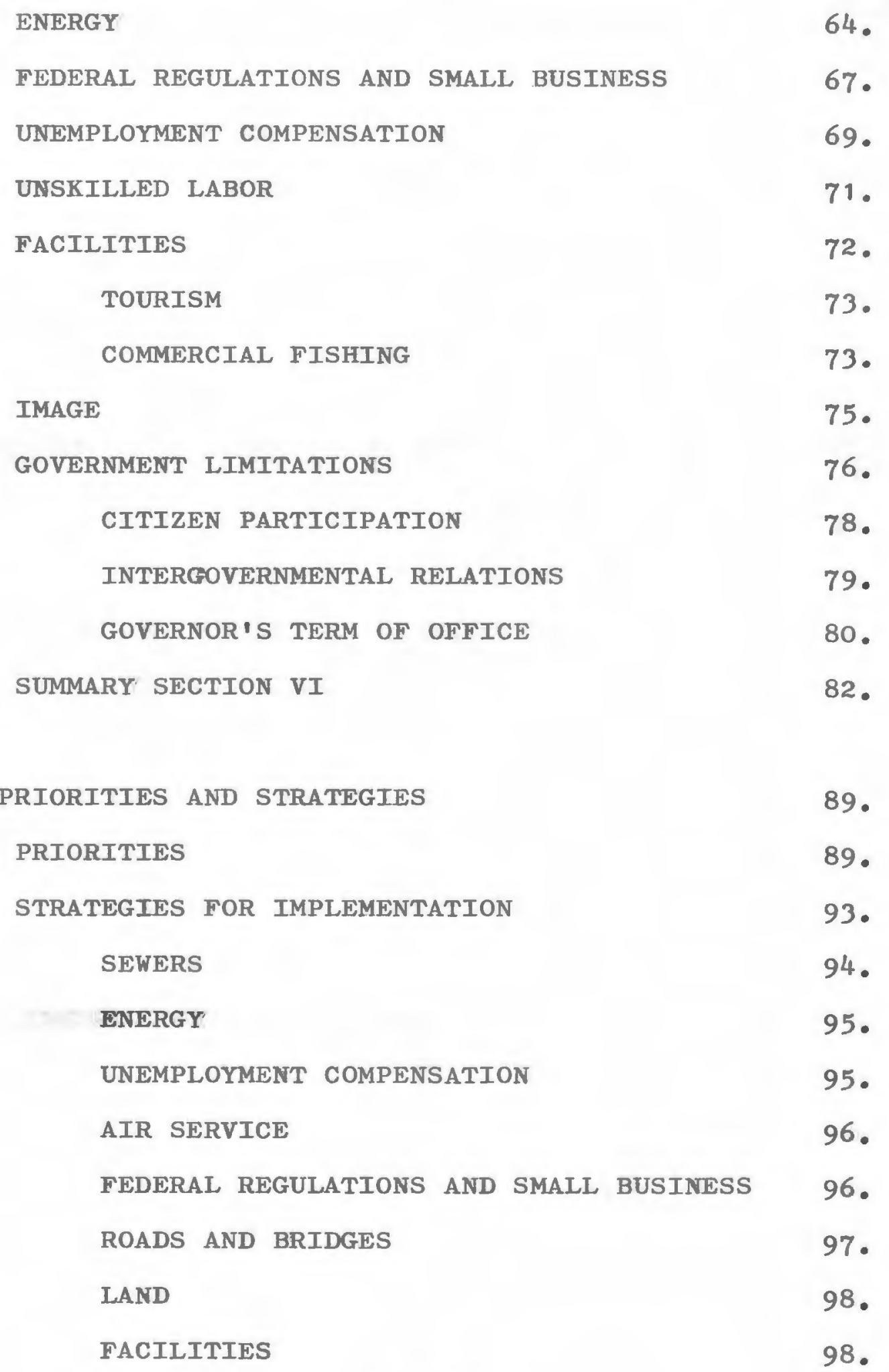


LANL SINAGENATT TOI,ICY

99.

B.1Y SIIIPING

99.

WATER PROJECTS

100

RAILLAY L'RLSERVITION

100

GOVLRYOR'S TERM OF OFFICE

101.

AIPENDIX

iv. 
T. $\perp$ BLPS

page

TABLE I

TROUUCTION WORKLR EARNINGS IX ILL

MAUFACTURT:G IXDUSTRIES IN THE

NORTHEAST - AUGUST 1978

11.

TIBLE II

VALUE IDISD B: MINUFACTURE PER MAN

HOURS 1972 CYNSUS OF MNUF.ICTURERS

11.

TABLE III

ENCRGY CUSTS, NEW FNGLAND vs. U.S.

65.

Ts $\ B L E I V$

LABOR DISJUTE RECORD: 1971-1976

14 INDUSTRIAL STATTS AXD TIE U.S.

77.

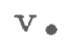


páge

FIGURE

DISTRIBUTLEN UT TOTAL WAGR AVI) SILARY

EVILCYMNT IX RIODE ISLAND 1958 ¿ $1976 \quad 6$.

FIGULE II UNLAPIOYMENT AS A PLRCONTIG: OF

CIVILIAI LABOR FORCE 1947-1978

RHODE IST.AND AND U.S.

9.

FIGURE III RHODE ISLAND POPTLATION BY IGE AND

SEX 1970 U.S. CWNSUS

13.

FIGURE IV RHODF ISLAND WOTENTLA GROLND WITIR

STUDY AREAS 24.

FIGURE: $V$ RIODE ISLANJ MAJOR SURFACE WATER

SUP'TIES

25.

vi. 
Before beginning to discuss economic development as it relates to Rhode Island, it seems worthwhile to discuss what is meant by "economic development" as referred to in this work. Economic development can take many forms and involve a multiplicity of actors, some of whose roles are not immediate1y apparent.

The most common image of economic development is that of the process of firm attraction. Firm attraction is an important part of economic development. It usually consists of efforts to attract investment from firms located outside of the subject area. In the case of Rhode Island for example, it might involve attracting investment by firms from some other state or nation. It may involve the relocation of a firm or the construction of a new branch of a firm.

Whereas this is perhaps the best known met od of economic development, far too few firms relocate, or establish branches each year for attraction to fulfill all of the job needs of an expanding labor force such as Rhode Island's. A much more important form of economic development is that of providing expansion incentives. This method focuses on firms indigenous to the subject area. Incentives may take the form of tax incentives, provision of 
low interest capital, rezoning or other techniques. This should be the backbone of any economic development effort. As used in this work, economic development refers to any process which enhances the economic climate of an area. As such, this includes firm attraction and expansion incentives but is not limited to them. It includes many processes which may not normally be associated with economic development such as urban revitalization, housing improvements, education, and road construction as well as many others. Even such activities as litter clean up campaigns can affect economic development by improving the appearance and image of an area.

According to this interpretation, economic development includes a variety of participants, as any individual or organization taking action that might enhance the economic climate of an area is involved in the process of economic development. Conversely, any individual or organization taking action which detracts from the economic climate of an area can be said to impede economic development. The use of economic development in this way is based on the conviction that economic development is a process which affects, and is affected by, anyone participating in economic activity. It is not the responsibility of any individual or any individual government, but is the collective responsibility of all. 


\section{BACKGROUND}

\section{IIISTORY}

It is easiest to understand the nature of the modern Rhode Island economy by examining Rhode Island's past economies. Settled in 1636 as a "1ively experiment....in religious concernments" on the part of Roger Williams and followers, Rhode Island has a long history. Early settlers fished and farmed to sustain an agricultural economy. New England's stony soils are less than optimum for agriculture, however, and agriculture soon gave way to trade, services and manufacturing. In 1793 the American industrial revolution began in Pawtucket, Rhode Island with the construction of the first cotton mill in the nation by Samuel Slater. It was the first of many as, favored with a natural deep water port, Narragansett Bay, and supplied with abundant water power from the state's rivers, Rhode Island industry flourished. Construction of railways in the 1800 's further enhanced Rhode Island's industrial advantages as a major coastal rail line passed directly through the state. This served to link the seaports of Rhode Island, and Rhode Island industry, more closely with the large market which developed with the concentration of population on the east coast. 
As a part of this population concentration, Rhode Island could provide ample labor for industrial growth. With an industrial emphasis on labor intensive, low value added manufacturing, Rhode Island offered abundant jobs to waves of immigrants who arrived seeking the "New World". Based in textiles, appare1, and metal working, Rhode Island's economy flourished.

World Wars brought the military to Rhode Island in considerable numbers. As Narragansett Bay's natural deep water port favored commercial shipping, it also favored military shipping, and Quonset Point Naval Air Station was one of the primary jumping off points for the European campaign of World War II

Shortly after WWII however, Rhode Island's economy suffered a severe set back. The textile industry, plagued by intensive competition from imports and older, inefficient equipment, began a long term decline. As the movement of population concentration westward had moved markets further west, and the evolution of new kinds of power had weaned industry from its dependence on water power, Rhode Island's competitive advantages for industrial location were considerably diminished. Many textile firms moved to less developed areas, where labor was not yet unionized and labor and tax costs were comparatively less than those of New England. Rhode Island lost an estimated 47,000 textile jobs out of a to- 
tal number of jobs in the vicinity of 300,000 for al1 types of employment. 1

While this was a severe blow to the state economy, Rhode Island was not left without resources. It still had a seaport and many other industries besides textiles. Of these, the one which took prominence was the jewelry industry. This industry quickly flourished in the abundant space left by the departure of textile firms. As it grew, it employed many of those in the labor force who had been left unemployed by the decline of the textile industry. Today, Rhode Island's largest manufacturing industry is that of jewelry and silverware production. ${ }^{2}$ This is also a major export industry as Rhode Island is the nation's largest manufacturer of body and costume jewelry. 3

The Rhode Island textile industry did not completely collapse, but it has become a less important part of the state economy. As shown by figure I, in 1958, when manufacturing provided $40.9 \%$ of total civilian employment, textiles and jewelry/silverware production provided $10.8 \%$ and $6.8 \%$ of this employment respective1y. In 1976 by contrast, when manufacturing provided $33.4 \%$ of employment, jewelry/silverware production provided $7.3 \%$ and textiles on 1 y $3.4 \%$.

Note that these figures seem to show a decreasing dependence on manufacturing in the Rhode Island economy, from $40.9 \%$ in 1958 to $33.4 \%$ in 1976 . This $7.5 \%$ decrease 
FIGURE I

DISTRIBUTION OF TOTAL WAGE AND SALARY

EMPLOYMENT IN RHODE ISLAND 1958 \& 1976
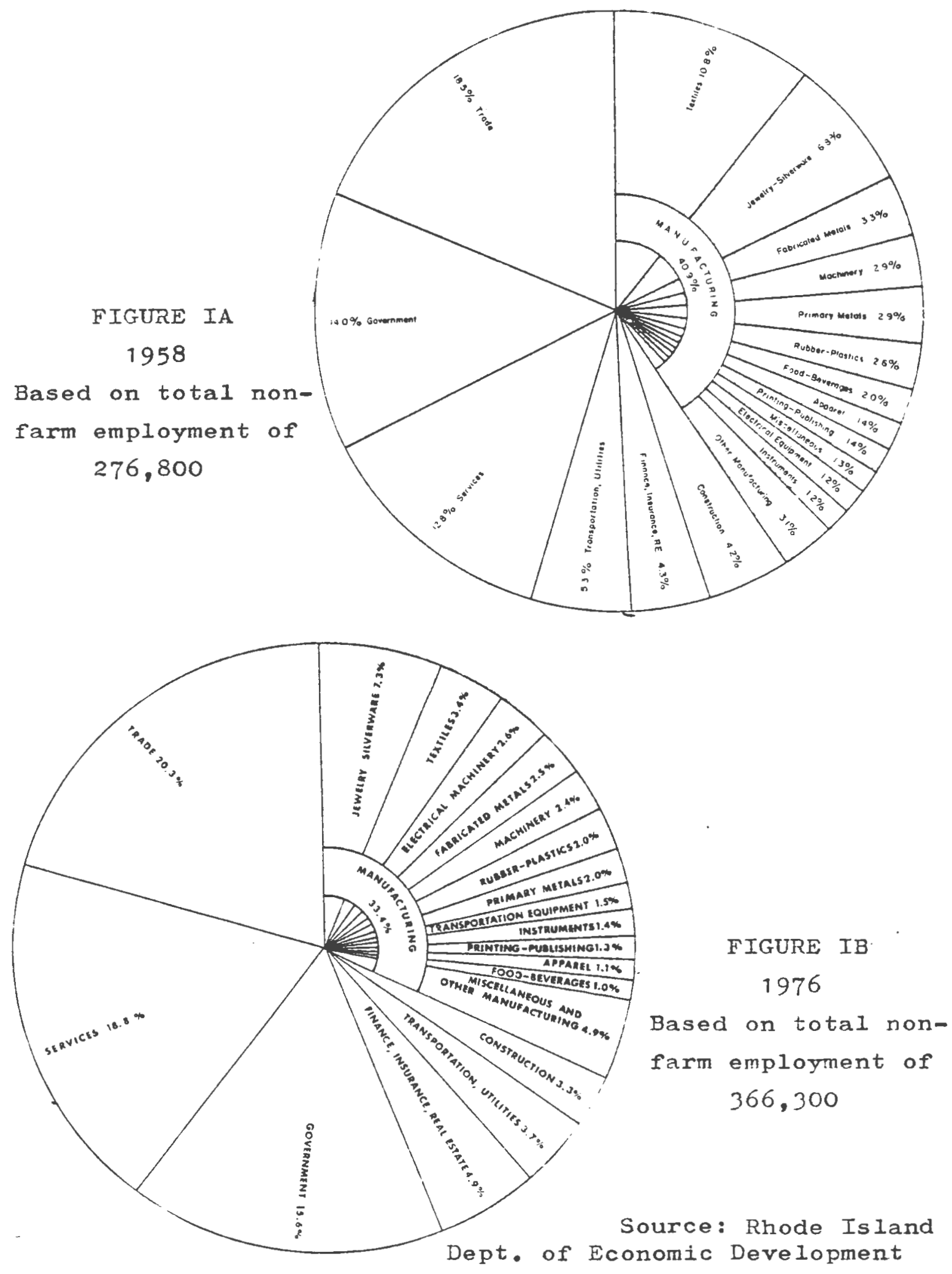
in the percent of total employment concentrated in manufacturing seems closely related to the $7.4 \%$ decrease in total employment provided by the textile industry.

These figures do not tell the whole story as they reflect only civilian employment. As previously stated, the military was an important part of Rhode Island's economy. In 1973, the U.S. Navy began an extensive reduction in it's national forces, $50^{\circ}$ of which would occur in Rhode Island. 4 20,000 military and 6,000 civilian jobs were affected in the state at a time when total civilian employment was $394,500.5$ This loss of jobs was considerably less than that resulting from the decline of the textile industry but occurred over a much shorter time period. Because of its sudden nature, and because it came in the midst of the national economic recession of the early 70 's, this was a particularly severe blow to Rhode Island's economy. Navy cutbacks brought Rhode Island its first significant population decline. U.S. Census data indicates a population of 949,723 on April 1, 1970 and an estimate of 939,420 on July 1,1976 reflecting a statewide decline of 1.1\%.6 More significant are the figures for Middletown and North Kingstown, two towns which had been hosts to Naval bases. Middletown lost 13,115 persons or $44.8 \%$ of its total population and North Kingstown lost 10,019 persons or $33.6 \%$. Unemployment soared to a post war high of $14.8 \%$ in 1975.7 
This was a blow which Rhode Island could weather however, and, thanks to quick action on the part of state government, unemployment was back to a manageable $6.7 \%$ by 1978. 8 In fact, by September, 1978, total employment in wage and salary jobs in the state reached 405.6 thousand, the highest level ever recorded. 9

Temporary prosperity does not mean that Rhode Island need not be concerned about economic development. The need for continued economic development efforts is still apparent in the state and becomes obvious with close examination of a few economic indicators.

\section{THE NEED FOR ECONOMIC DEVELOPMENT}

Perhaps the most significant indicator of the need for economic development in Rhode Island is the past record of the state economy. Twice the state has had to weather severe economic blows. Twice it has recovered. But development requires more than just recovery. Further efforts are needed to provide protection from future such crashes by broadening the state's economic base and decreasing dependence on individual industries. Another indicator of the need for further economic development for Rhode Island is the state's unemployment rate. Figure II shows Rhode Island unemployment as a percentage of civilian labor force, as annual averages for the period 1947-1978. Note the number and height of the 
Figure II

UNEMPLOYMENT AS A PERCENTAGE

OF CIVILIAN LABOR FORCE

1947- 1978 ANNUAL AVERAGES

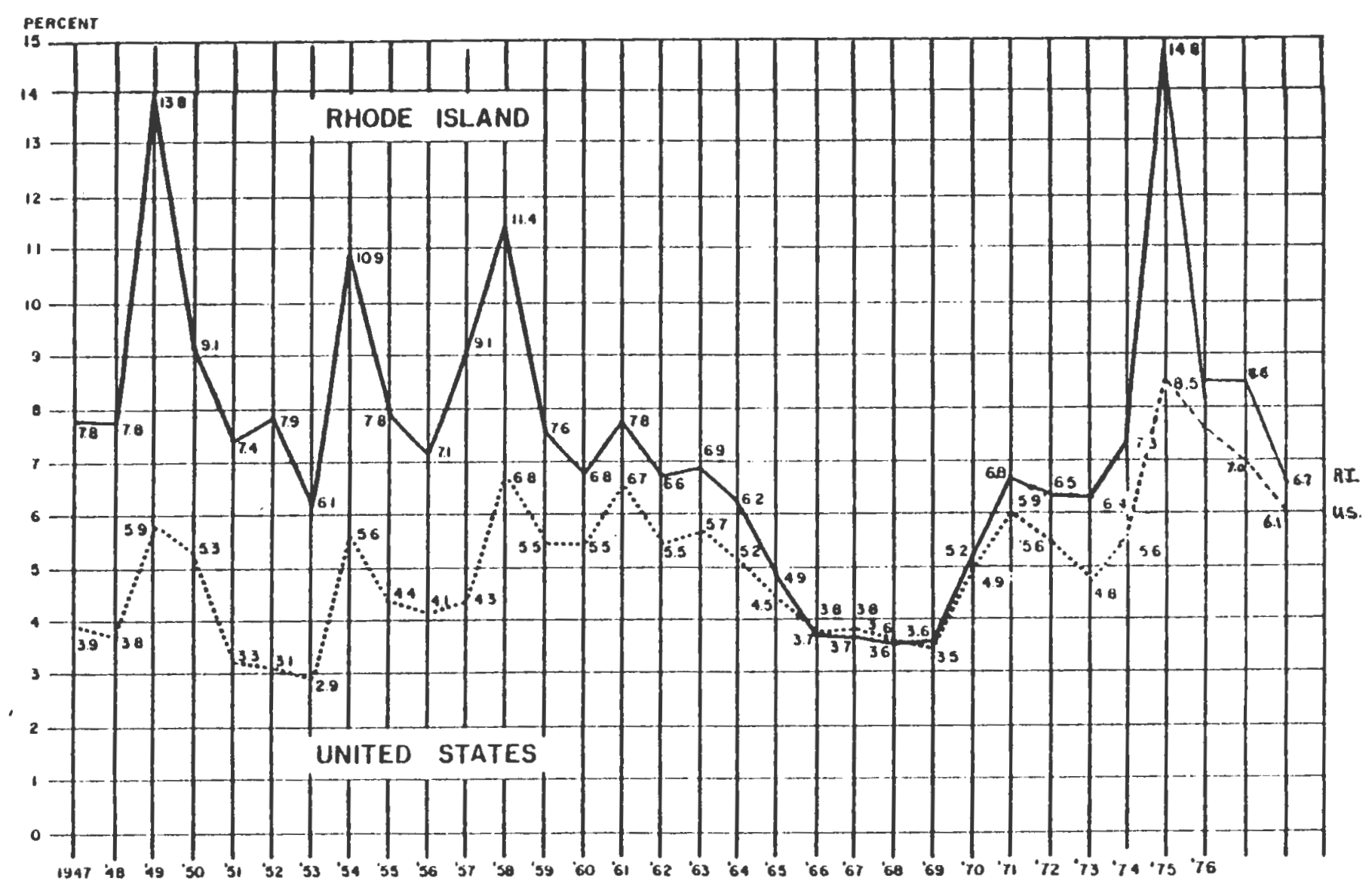

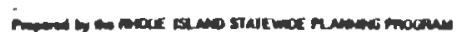


peaks of unemployment, suggesting that Rhode Island's economy is very "volatile", that is it has not been charecterised by employment stability but by large fluctuations in employment.

Note also how Rhode Island's employment responds to national trends, seeming to suffer the worst of bad national trends and approaching national averages only in the period of extreme prosperity during the late 1960's. Part of this may be due to Rhode Island's dependence on manufacturing, an economic sector which is particularly sensitive to economic recession. It may also be due to the preponderance of small firms which compose Rhode Island manufacturing. The average jewelry firm employed 24 persons in $1975 .^{10}$ Such small, family owned businesses often lack the reserve capacity to maintain full employment during periods of economic recession.

There are other indications of the need for economic development. As shown by Table I, in 1978 Rhode Island's averafe hourly manufacturing wage was the lowest in the northeast. Rhode Island's low wage status may be a reflection of the nature of Rhode Island manufacturing where the emphasis is still on labor intensive, low value added production. Table II shows how Rhode Island's value added perman hour (average) lags behind national and regional values as well as those of its neighbors. 


\section{TABLE I}

PRODUCTION WORKER EARNINGS IN ALL

MANUFACTURING INDUSTRIES IN

$$
\text { NORTHEAST - AUGUST } 1978
$$

Average Hourly Rate

\begin{tabular}{lr} 
MARYLAND & $\$ 6.56$ \\
PENNSYLVANIA & 6.40 \\
DELAWARE & 6.39 \\
NEW JERSEY & 6.20 \\
NEW YORK & 6.04 \\
CONNECTICUT & 5.94 \\
UNITED STATES AVERAGE & 5.70 \\
MASSACHUSETTS & 5.54 \\
VERMONT & 5.14 \\
NEW HAMPSHIRE & 4.96 \\
MAINE & 4.85 \\
RHODE ISLAND & 4.69 \\
\multicolumn{1}{c}{ Source: U.S. Department of Labor }
\end{tabular}

TABLE II

VALUE ADDED BY MANUFACTURE PER MAN HOURS 1972 CENSUS OF MANUFACTURERS MASSACHUSETTS $\$ 13.40$ CONNECTICUT $\quad 13.30$

UNITED STATES $\quad 13.30$

NEW ENGLAND $\quad 12.20$

RHODE ISLAND $\quad 10.20$

Source Memo to NERCOM from R.I. DED, 9/26/75 
This type of low value added, labor intensive industry traditionally has relied on unskilled and semi-skilled 1abor and consequentially has not been charecterised by high wage rates.

It also has not demanded high educational achievement on the part of employees. Nany Rhode Islanders leave school early for production jobs in the mills and factories. According to the 1970 Census on 1 y $46.4 \%$ of persons 25 or older in Rhode Island had completed four years of high school or more. Comparable figures for Massachusetts and Connecticut are $58.5 \%$ and $56.0 \%$ respectively.

Limited skill and education requirements, low wages, and high unemployment all serve to reduce the investment employers have in their employees. This sets the stage for employment instability by reducing the commitment of employers to individual employees, an observation which helps to explain the numerous peaks and valleys on the solid line in figure II. All of these factors show that there is room for improvement in Rhode Island's economy. Still further indication of the need for economic development in Rhode Island comes from analysis of population and labor force trends. While Rhode Island's population decreased by $1.1 \%$ in the years between 1970 and 1976, the state's labor force increased by $8.9 \%{ }^{11}$ There are a number of explanations for this. One is suggested by the population pyramid in figure III. 
FIGURE III

RHODE ISLAND POPULATION BY AGL AND SEX

1970

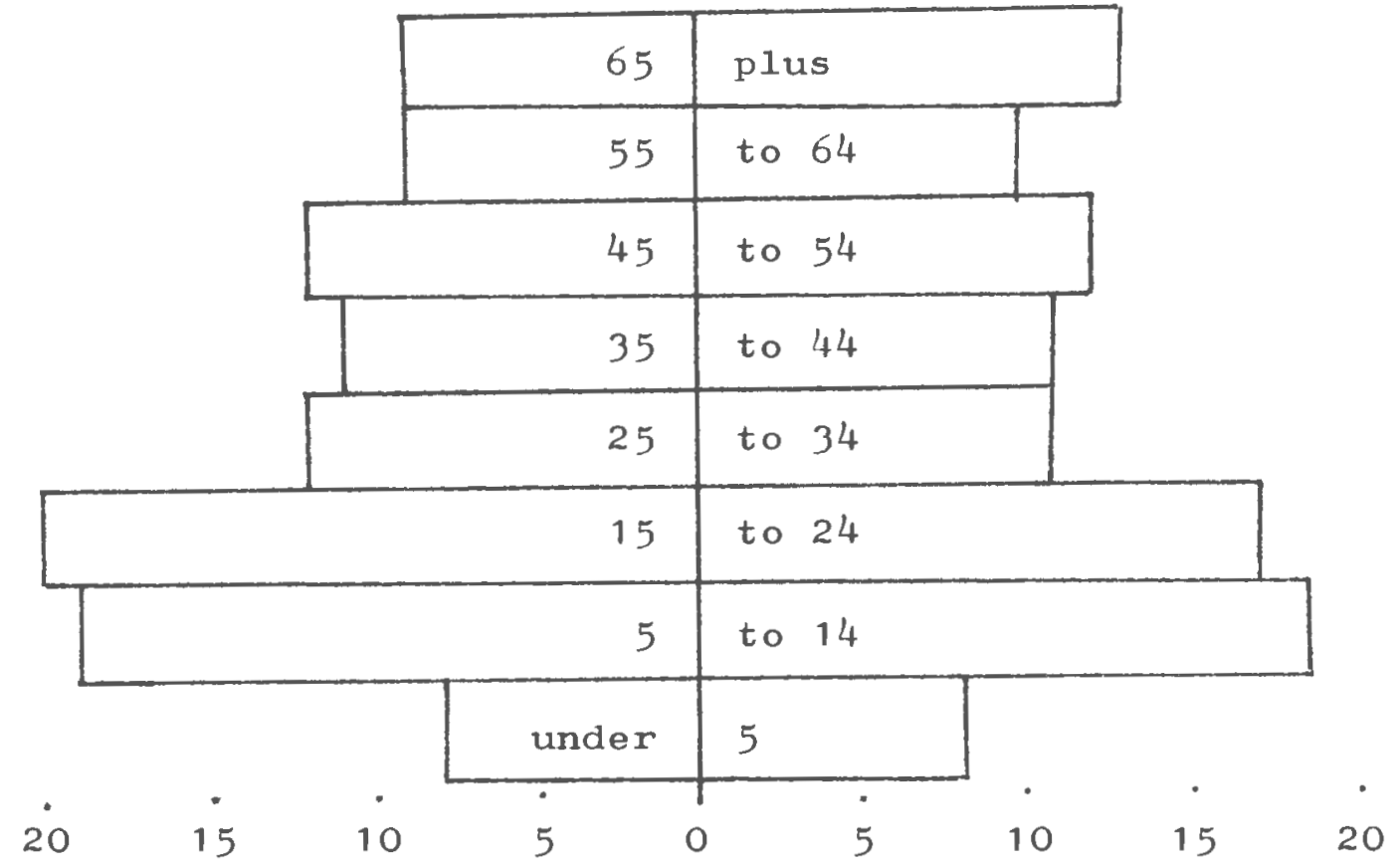

percent

Source: U.S. Dept. of Commerce, Bureau of the Census 1970

Note the wide base representing persons between 5 and 24 years of age in 1970. These individuals are the product of the post WWII "baby boom". They are now coming of age and entering the job market, swelling the labor force.

Further contributions to the labor force have resulted from changing social mores which have expanded the role of women in the labor force and from rising inflation which has led many families to seek extra earnings with second jobs or additional working family members. This 
argument is supported by the fact that Rhode Island, in spite of low wages, has a per capita income just slightly below the national average and ranked $20^{\text {th }}$ out of all 50 states for per capita income in $1975 .{ }^{12}$ Because of expansion in the labor force, the Rhode Island Statewide Planning Program estimates that Rhode Island must supply an average of 4,500 new jobs annually during the period 1970 to 1980 in order to maintain an average annual unemployment rate of $8 \% .13$

It is for these reasons that economic development has been, and must continue to be, a primary concern of state government in Rhode Island. It should be important to all Rhode Islanders concerned about unemployment and eager to see economic growth and stability in the state. Economic development is not a magic process which materializes from thin air. It provides benefits but requires commitments, commitments which Rhode Islanders must be prepared to make. Rhode Island presents an environment of varying quality for economic development, blessed with many resources and yet faced with limitations. The remainder of this work is devoted to an examination of these assets, resources, and limitations leading to a discussion of priorities for commitments to economic development by Rhode Island's citizens and government. 


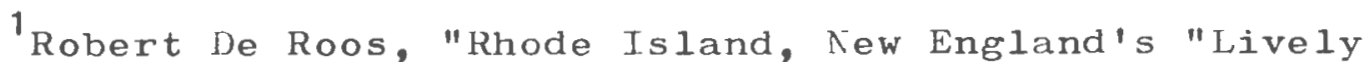
Experiment", Nat'1 Geographic Magazine, Sept.,1968 p. 373

${ }^{2}$ Rhode Island Department of Economic Development, Rhode Island Basic Economic Statistics-The Economy, Summary and Trends, (Providence 1978), p.24

3 Steven Walton, "Location Dynamics and the Jewelry Industry in Rhode Island" (Nimeograph: 1977), p. 2

${ }^{4}$ Rhode Island Department of Economic Development, "Rhode Island: Its opportunities Can't be Measured in Square Miles", Forbes, May 15, 1977

${ }^{5}$ Rhode Island Department of Economic Development, op. cit. \#2 p. 22

${ }^{6}$ U.S. Department of Commerce, Bureau of the Census Current Population Reports, Population Estimates and Projections Series P-25, No. 778, Jan. 1979 p. 7

${ }^{7}$ Rhode Island Statewide Planning Program, Overall Economic Development Program, Nov. 1977 p. III-4

${ }^{8}$ Vincent Calitri, R.I. Department of Employment Security. Telephone interview Tuesday, November 14, 1978

$9^{\text {Ibid }}$

${ }^{10}$ Rhode Island Dept. of Econ. Dev. op cit. \#2 p. 104

11 Ibid p. 21

12 Ibid p. 23

${ }^{13}$ Rhode Island Statewide Planning Program, Jub Need in Rhode Island, Estimating the Number of Jobs Needed 1970 -1985 Technical Paper Number 72, June 1978 p.i 


\section{ADVANTAGES AND DISADVANTARES OF DEVELOPNENT}

To be fair, it must be pointed out that economic development is not an exclusively "good" thing. Like almost anything else, economic development has advantages and disadvantages. Decisions on economic development policy should be made in full recognition of these advantages and disadvantages. Rhode Island cannot expect to get something for nothing through economic development. Development can bring substantial improvements for the state's economy but there are prices which must be paid.

\section{ADVANTAGES}

Economic development can provide a number of significant improvements to the state's economy. First, by providing jobs for more Rhode Islanders, it can assure that those in need of jobs have the opportunity to find them. This can reduce unemployment and ease the burden on state services for the unemployed, freeing funds for use in other programs.

Second, it can help to stabilize the state's economy by providing a diversified economic base. This will help to prevent the recurrence of the economic crashes Rhode Island has experienced in the past due to overdependence on individual industries. Creation of a diversified econ16. 
omic base can also improve the selection of jobs available to Rhode Islanders. There can be not only more jobs available but more types of jobs from which to choose. This can help to reduce the volatility of the Rhode Island economy by offering individuals more alternatives to unemployment.

Third, economic development can he1p to reduce Rhode Island's economic sensitivity to national trends by reducing dependence on extremely sensitive industries. Growth of local industry and attraction of foreign investment can help assure sufficient reserves to ride out periods of national economic recession.

Fourth, economic development can help to ease the tax burden on private citizens in Rhode Island cities and towns. Tax dollars which are supplied by business and industry are tax dollars which do not have to be provided by private citizens. While it would be unrealistic to suggest that taxes might decrease, assumption of more of the tax burden by business and industry can slow the rate of increase for private taxpayers.

Last, economic development can improve the standard of living of Rhode Islanders. More jobs, more types of jobs, reduced unemployment, and lighter tax burdens, coupled with intensive efforts to upgrade the labor force, mean more money available to Rhode Islanders. This money can be used for consumption or for investment, thereby perpetuating the cycle and improving the availability of 
funds. Higher standards of living can also recluce the burden on the state's social service system, again freeing funds for other priorities.

\section{DISADVANTAGES}

Al1 this improvement is not won without a price however. Economic development has undesireable consequences as well as benefits. There are a number of trade offs which must be made for economic development.

First, economic development results in accelerated use of natural resources. With careful management, this need not deplete renewable resources such as wood or fresh water but depletion of nonrenewable resources such as minerals, coal and oil will inevitably be accelerated. Further, finite resources, particularly land, will also be consumed at a faster rate. Once expended, these resources cannot be recovered and will not be available for successive generations. Accelerated economic activity can appreciably shorten the time these resources will last. Second, economic development and consequential accelerated economic activity can produce environmental degradation. Phenomenon such as the disposal of industrial wastes, construction of facilities, and increased population resulting from economic development place heavy demands on natural systems. In many cases, this can have irreversible impacts and can threaten the operation of ecological systems. 
Third, and closely associated with environmental degradation, is a decrease in the quality of life which can result from economic development. Some people find the accelerated urbanization and industrialization which can be associated with economic development undesireable. Most find serious environmental degradation objectionable. Loss of natural resources, urbanization and industrialization, and environmental degradation can represent substantial decline in the quality of life.

These disadvantages are not inevitable. While little can be done to prevent the accelerated use of resources resulting from economic development, economic development need not result in considerable environmental degradation or decrease in the quality of life. Through the use of land use controls and environmental protection regulations some of the negative effects of development can be mitigated. 
Rhode Island is not without resources. Certainly the state has many valuable assets which provide good potential for economic development. Few Rhode Islanders take time to consider some of the many attributes and advantages of their state. Many will therefore be startled at their number and diversity. For purposes of discussion these assets have been grouped into four major categories, natural resources, quality of life, economic advantages, and assets in government.

\section{NATURAL RESOURCES}

COASTAL ZONE

Perhaps Rhode Island's most valuable asset is its 419 mile coastline. ${ }^{1}$ The coastal zone, including the Rhode Island territorial waters, shoreline, coastal wetlands and estuaries, and particularly Narragansett Bay, provides the state with a great diversity of economic activity.

The state makes use of its coastal systems for a great variety of activities which provide utility or generate funds for residents. Among these are, shipping, fishing, recreation, sports, tourism, aquaculture, and sewage disposal. Several of these activities, particularly shipping, tourism, and aquaculture, show good potential for future expansion. 
According to the Rhode Jsland Coastal Zone Management Plan, shipping, particularly in the lort of Providence, has a major economic impact on the state through: direct and indirect employment; taxes and duties; dockage, wharfage and storage fees; vessel and crew servicing, refueling and repair; and stimulus to trucking and railroad business. $^{2}$ Furthermore, import/export patterns in Rhode Island over the last ten years indicate an erratic pattern of slow net growth, suggesting the possibility of future continued growth. 3

The Port of Providence is Rhode Island's major commercial shipping seaport and is a major regional port for such products as petroleum, automobiles, lumber, and scrap iron. Imports accounted for 98\% of total 1976 tonnage handled and petroleum products accounted for $93.5 \%$ of imports. Bulk and general cargo traffic has increased significantly in recent years, especially foreign automobile imports, and support trends and port improvements suggest that bulk and general cargo will be the dominant growth sector in the foreseeable future. 4

As growth in shipping can bring economic development to Rhode Island so can growth in commercial fishing. The implementation of species management made possible by the new 200 mile U.S. fishing limit may promise unprecedented yeilds and dreamatic growth in the Rhode Island fishing industry. 
Aquaculture, once one of the state's most inportant marine businesses, may again provide significant economic contributions in the coastal zone. The Rhode Island cultivated oyster industry peaked in 1910 when 15.3 million pounds of oysters were harvested from some 21,000 acres of leased bottom in Narragansett Bay but is virtually nonexistant today. 5 Although there are significant problems with pollution and conflicting uses, the recent small scale revival of oyster farming on Narragansett Bay may foretell a renewal of Rhode Island aquaculture.

Tourism is another coastal activity which shows promise for future economic development. Increases in tour ism over the past few years, such as that which occured in Newport, Rhode Island between 1973 and 1977, indicate that the potential of the coastal zone for tourism is only just being realized.

Considering the enormous amount of economic activity generated by the coastal zone, and the promising potential for growth in many coastal activities, there can be little doubt of the importance of the coastal zone to the Rhode Island economy. But while the coastal zone may be the state's most important natural resource, it is not the state's only water related resource. Rhode Island is well endowed with fresh water as well as salt. 
FRESH WATER RESOURCES

With an average annual rainfall in excess of 40 inches, Rhode Island often has more water than it needs. For the most part, Rhode Islanders take the state's abundance of fresh water for granted and lack the respect for water which is found in more arid areas. Fresh water is valuable. It is essential to all living things and a vital part of many industrial processes.

Water circulates through a complex series of pathways known collectively as the hydrologic cycle. Most of the water used for human consumption comes from one path of this cycle, that of runoff. It is usually taken from either surface waters or ground waters. Rhode Island has a great deal of both.

Ground water in Rhode Island is still a largely untapped resource. Figure IV, page 24, shows areas of glacial outwash representing potential reserves of ground water in the state. It is not known exactly how much ground water flows through Rhode Island and is available for exploitation but that which has been tapped has proven abundant and, depending on the location, of high quality. In some instances a single well, tapping gravel bodies, has yielded as much a four million gallons daily. 6

Most of Rhode Island's water supply does not come from ground water but comes from surface water. Figure $\mathrm{V}$, page 25 , shows existing and potential surface water 


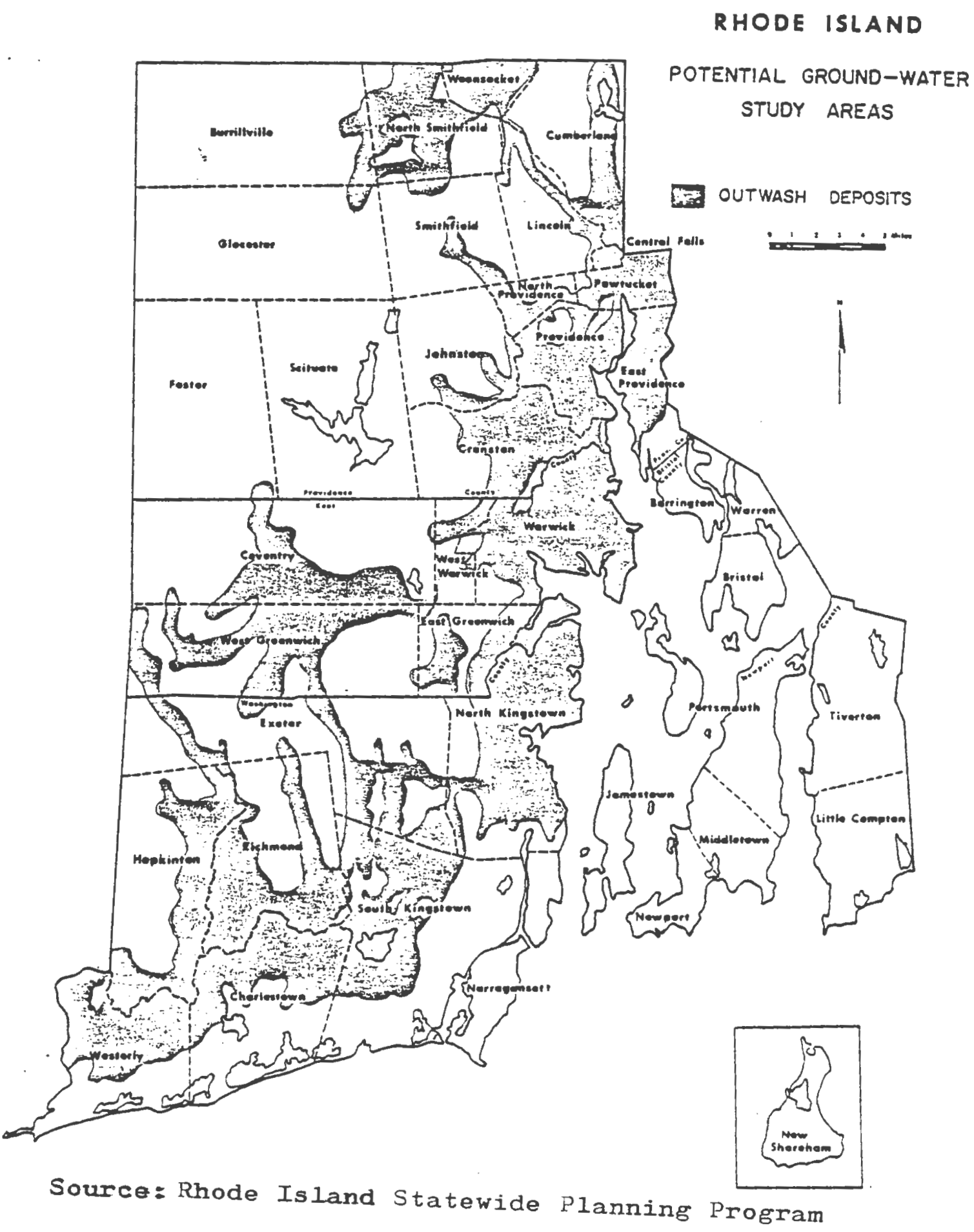




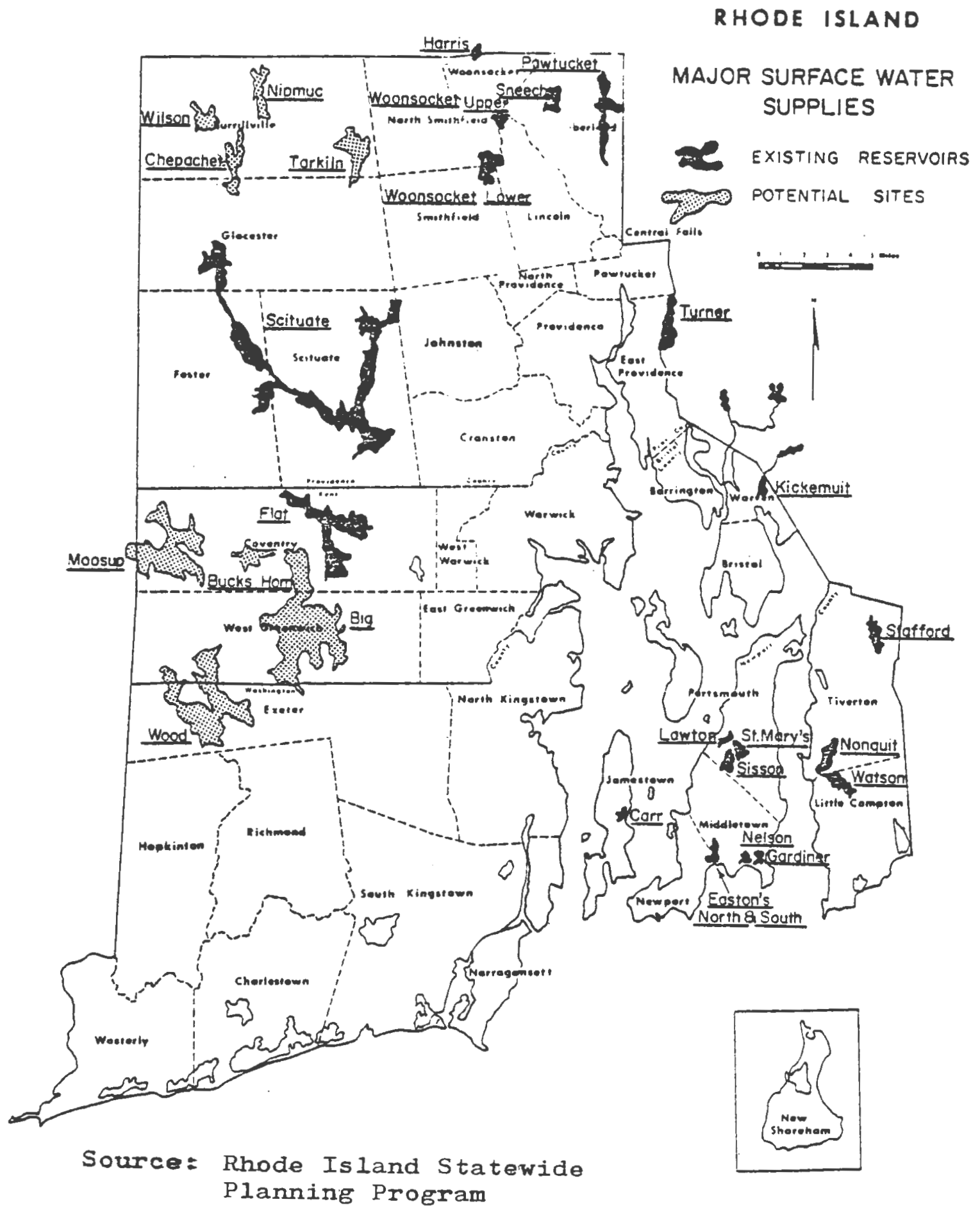


storage for supply systems. The Scituate Reservoir, source for the largest water supply system in the state, has a yield of about 84 million gallons per day. 7

Surface water serves Rhode Island in other ways than as a source of water for drinking and industrial processes. It also offers Rhode Islanders recreation opportunities. Rhode Island contains 165 square miles of inland water, more than $13 \%$ of the state's total area. 8 These waters are used for fishing, boating, and swimming by thousands of Rhode Islanders annually. They provide refuge and food for wildlife, and enhance the appearance of residential areas thereby enhancing property values.

Also, Rhode Island's surface water provides a convenient means of effluent disposal. Sewage effluent is composed mostly of water. Water which must at some point be re-introduced into the hydrologic cycle. After treatment, effluent can be dumped into rivers which carry it off and break it down biologially. Rivers and streams also carry away runoff waters, preventing flooding. In this capacity they are aided by the storage capacity of wetlands and floodplains which release water slowly, preventing flash floods.

In earlier days, the rivers and streams that flowed through Rhode Island were vital to industrial development because they supplied water power. Of late, water power has been of decreasing importance in the state. There 
were 460 water wheels in operation in Rhode Island in 1875 but only 4 in 1972.9 Perhaps as other types of energy become more expensive water power may again become a natural resource of economic importance. *

LAND

At first glance, land would not appear to be one of Rhode Island's assets. At 1,214 square miles in area, it is the smallest of all fifty states. ${ }^{10}$ According to the last census, it was also the second most densely populated state with 905 persons per square mile. 11 In spite of this however Rhode Island still contains a great deal of open space. Only slightly more than one third of the state's surface area has been developed. 12

Most of the population is clustered in the eastern purt of the state, leaving the western part largely undeveloped. The extreme concentrations of population around upper Narragansett Bay tend to raise the overall average density figures and give the impression that the entire state is densely populated. For example, the state's most densely populated community, Central Fal1s, in the northeastern part of the state, has a population density of 15,597 persons per square mile. In sharp contrast is Fos-

* The growing importance of water power is indicated by such projects as the Rhode Island Governor's Energy Office study of hydro power and the New England River Basins Commission's "Low-Head" hydro project currently underway. 
ter, the state's least densely populated mainland town 1ocated in the western part of the state. Foster has only

51 persons per square mile.

Most of Rhode Island's total land area is developable. Only about $5.3 \%$ consists of steep slope, rock, swamp, or other extremely limiting terrain; and because of the state's small size, no area is too remote to develop. 13

Fifty nine percent of total area is currently in forests, 14 an indication that there is still much undeveloped land in spite of appearances to the contrary.

Undeveloped space may not be as important to Rhode Island as is previously developed space. A long legacy of manufacturing and past economic turbulence has left a number of vacant, former industrial space ranging from textile mills more than 100 years old to recently abandoned naval bases. The availability of this space, at relatively inexpensive rates, has helped to make Rhode Island an incubator for small business.

\section{OTHER NATURAL RESOURCES}

Rhode Island contains many other natural resources. Retreating glaciers left considerable deposits of sand and gravel, of major importance to the construction industry. The value of mineral production, of which $70 \%$ consisted of sand and grave 1 mining, totaled $\$ 4.8$ million in 1975.15 Limestone, a mineral used in the manufacture of cement and 
in agriculture, is mined at Limerock, in the town of Lincoln. Cumberlandite, an ore containing titanium and iron, is found in Cumberland, Rhode Island at Iron Mine Hill and Rhode Island's bedrock, which crops out in numerous places, is a hard grey granite, quarried for construction and for grave markers.

Rhode Island may contain deeply buried deposits of low sulfur coal in Newport and Bristol Counties. Preliminary data suggests that some 15 million tons of mineable coal may lie within Rhode Island. ${ }^{16}$ Rhode Island is also fortunate in being located in close proximity to potential deposits of offshore oil and gas and in an excellent position to serve as home base for drilling operations.

The forest which covers more than half of the state produces abundant wood products. Climax forest consists, for the most part, of hardwood, oak and hickory, both of which yeild high heat per cord when burned. Some softwood is also grown in the state and cut for lumber.

Other natural energy sources include water, mentioned above, solar radiation, and wind. Rhode Island recieves an amount of solar radiation in a year equal to many times total annual energy consumption. Very little of this energy is trapped and used by Rhode Islanders. Wind energy is generated by the interaction of air over water and land surfaces in the state. Winds average 10.7 miles per hour in Providence, making it one of the nation's windiest 
cities. An experimental wind generator has been planned for construction on Block Island, Rhode Island to take advantage of this little used Rhode Island resource.

QUALITY OF LIFE

Quality of life may seem too abstract a concept to be contained in a work concerned with economic development, yet the quality of life or "liveability" of an area can contribute to or detract from that area's economy in a number of ways. Large corporations frequently use some form of quality of life consideration as part of site selection criteria. Liveability may be the deciding factor between otherwise similar locations. In addition, smaller businesses may be located based largely on the owner's desire to live and work in a certain area. A high quality of life in an area therefore serves to attract individuals and investment to that area. Quality of life is important to visitors as well as residents. Availability of a diversity of experiences within a small radius can add to the enjoyment visitors find in an area and encourage them to return. It may also encourage them to tell others of their experiences. For this reason a high quality of life can enhance a tourist economy.

Rhode Island's excellent liveability is one of its major assets. The Midwest Research Institute, in 1973 in 30. 
a report rating the quality of life nationwide, ranked Rhode Island in the top 10 of all 50 states as one of the most desirable places to live based on composit rankings for individual status, individual equality, living conditions, agriculture, health and welfare, technology, economic status, education, and state and local government. 17 While a lot may have happened in the six years since this study, Rhode Island still offers a diversity of cultural, recreational, educational and economic opportunities which not only make the state an attractive place to live and work, but serve to enhance the state's tourist industry .

The state contains twelve colleges and Universities including: Brown University, the seventh college in the nation; The Rhode Island School of Design with programs in photography, design, art, and architecture, and the University of Rhode Island, perhaps best noted for its graduate school of oceanography. As on of the earliest colonies, Rhode Island is rich in history and offers an architectural heritage as long as its history.

The state supports the arts, with a performing arts center in the capital city, a state philharmonic symphony orchestra and ballet company as well as many theaters. Perhaps the state's best known theater company is the Trinity Square Repartory company which not only offers entertainment but offers classes of instruction as well. 
In sports, to mention just a few things, Rhode Island is host to the America's Cup Yachting competition, intercollegiate competition in football and basketball and a Jai-alai sports theater. The state's natural resources offer recreational opportunities like boating, fishing, hiking, camping, surfing, and skindiving. There are over 50 parks throughout the state, numerous miles of hiking trails and over 100 miles of beaches, more than adequate to serve the needs of residents and tourists alike.

Health care is available through the state's 14 acute care general hospitals, three state-operated hospitals, and two federal hospitals. For emergency service, these hospitals are distributed largely in densely populated areas along main avenues of travel.

In summary, Rhode Island offers a very good quality of life. This is an important asset in that it makes the state an attractive place to live and work. It also helps to generate a positive impression of the state in other places and enhances the state's tourist industry.

\section{ECONOMIC ADVANTAGES}

PROXJMITY TO MARKETS

Rhode Island is in an excellent position for the distribution of goods throughout New England and the United States. According to the Rhode Island Department of Economic Development, $66 \%$ of New England's total population 
and eight of New England's 12 major Standard Metropolitan Statistical Areas are within 75 miles of Providence. 45 million people with a combined personal income of over $\$ 325$ billion live within overnight trucking distance, 300 miles, of Providence, and 142 million people with a combined personal income of over $\$ 925$ billion live within 1000 miles. 18

SMALL FIRM SIZE

As indicated in section two, Rhode Island business contains a number of small, family owned firms. Many of these, if provided with the proper growth incentives, may have good growth potential. Certainly all of the small firms in Rhode Island may not be capable of extended growth, and many may not be interested in growth, but small firm size indicates a possible potential for future conglomeration and expansion.

\section{LABOR}

Rhode Island's status as a low wage, high unemployment state may be an indicator of the need for economic development, but it is also a significant advantage for efforts at firm attraction. Since labor is the largest operating expense for most firms, firms tend to weigh labor costs very heavily in their site selection process. Rhode Island's low wages make it quite attractive to some 
industries. In fact, wages in New England are generally low enough to compensate companies for other higher costs of operation in the region. 19

Availability of labor is also very good in Rhode Island. The density of the state's population, and its small size, assures a concentration of labor near almost any site. Higher than average unemployment indicates that a large part of the labor force is seeking employment and therefore available. These represent significant economic advantages for Rhode Is land.

TAXES

The Navy pull-out in Rhode Island alerted the State legislature to the immediate need for action to save the state's faltering economy. Several actions were taken, one of which was tax reform. 1974 tax reform legislation included :

-Elimination of local property taxes on manufacturers new machinery and equipment purchased after 12-31-74, -Elimination of sales tax on manufacturer's purchases of machinery and equipment, -Special exemptions for Domestic International Sales Corporations (DISCs), -Replacement of corporate excess tax with a net worth $\operatorname{tax}$

$$
\text { -Write-offs for expenditures paid or incurred with }
$$


respect to research and development facilities, -An investment tax credit, -New operating loss carry back and carry forward provisions, -Special income allocation factors for multi-state corporations. As a result of this tax reform legislation, taxes on industry in Providence, Rhode Island in 1976 were lower than those in nearby industrial cities such as Hartford, Conn.; Worcester, Mass.; Newark, New Jersey; and Burlington, Vermont. 20 This new tax structure provides obvious incentives to business to invest in Rhode Island.

\section{AVAILABILITY OF CAPITAL}

There is a great diversity of financing programs available to business in the state of Rhode Island. Financing for new and existing firms is available through tax exempt revenue bonds, state insured 100\% mortgage programs, local development group programs and private financial institutions. Availability of capital helps to ensure new construction and major investment by both incoming and native firms.

\section{GOVERNMENT ASSETS}

GOVERNOR

The driving force behind government efforts for econ35. 
omic development is the state's Governor. This executive is responsible for the administration of all the many government agencies which contribute to the economic development process. In addition, in 1978 the Governor's office formed a "partnership" of business, labor, and government leaders to address the problems of Rhode Island's economy and to improve labor/management relations. The importance of this executive commitment to economic development cannot be overstated.

\section{DEPARTMENT OF ECONOMIC DEVELOHMENT}

Rhode Island is extremely fortunate in having a line agency of state government whose major responsibility is economic development. Divided into four divisions, Management and Planning, Tourist Promotion, Business and Industry, and Economic Statistics, the Department of Economic Development is one of the state's major assets. Dr. Gerhard Moog, a partner in the German owned firm of Kienhofer and Moog which recently decided to establish a 20,000 square foot production facility for the production of high-grade precious-metal watch cases in Lincoln, Rhode Island, was asked by Journal Bulletin reporters why the firm selected Rhode Island over some 17 other competing states. One of the things he said was "... The government department (DED) which handled the location of industry has been extremely helpful to us. They've given 
us all the information required". 21

In addition to the department's efforts to attract new business to Rhode Island it is also responsible for planning the use of surplus Navy property, promotion of the state's tourist attractions, and compiling and publishing economic cata. Its livision of Business and Industry operates a briefing center at Green state Airport in Warwick where potential industrial prospects are offered multi-media presentations of Rhode Island's assets. There is little doubt as to the benefits of this agency for economic development.

STATEWIDE I'LANNING PROGRAM

The Rhode Island Statewide Planning Program is the planning center for state government. Its primary responsibility is the maintenance of the State Guide l'lan, a series of elemental plans dealing with land use, utility services, transportation, recreation, historic preservation, and several other areas. The information and projections generated by this agency in the course of its activities is used extensively by both other government agencies and the private sector. The centralized planning function provided by this agency helps to assure coordination of economic development with other state goals and priorities. 
OTHER AGENCIES

In view of the broad interpretation given the terms "economic development" in this work, it is not possible to discuss all of the agencies which impact upon it. The profusion of public, private, and quasi public or quasi private agencies involved make this impractical. A listin of most of these agencies, prepared by the statewide Planning l'rogram, appears in Appendix A.

\section{SUAMARY}

Rhode Island is blessed with many advantages and assets for economic development. These often go unnoticed or are taken for granted by Rhode Island residents. Natural resources of many types, a high quality of life, numerous economic advantages, and assets of State government all combine to help improve Rhode Island's potential for economic development. 
${ }^{1}$ U.S. Department of Commerce, N.O.A.A., State of Rhode Island Coastal Management Program and Final Environmental Impact Statement, March, 1978 p. xiv

Ibid p. 174

${ }^{3}$ Rhode Island Statewide Planning Program, Rhode Island Transportation Plan-1990, Report \#19, 1973

${ }^{4}$ U.S. Department of Commerce, N.O.A.A., op.cit p. 175

${ }^{5}$ Ibid p. 68

${ }^{6}$ Rhode Island Department of Economic Development, Rhode Island Basic Economic Statistics-The Economy, Summary and Trends, (Providence 1978), p. 167

$7_{\text {Rhode Island Statewide Planning Program, plan for }}$ the Develpment and Use of I'ublic Water Supplies, Report \#10, Sept., 1969 p. 22

${ }^{8}$ U.S. Department of Commerce, Bureau of the Census, Area Measurcment Reports, GE-20, No. 41, Apr. 1967

${ }^{9}$ U.S. Dept. of Commerce, N.O.A.A. op.cit, th 1 p. 76

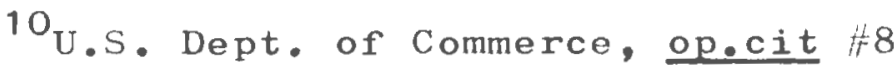

${ }^{11}$ U.S. Dept. of Commerce, Bureau of the Census, Characteristics of the Population, Vol. 1, Part 41, R.I.

12 Rhode Island Department of Economic Development, Rhode Island n.d., n.p., n.pag.

$13^{3}$ hode Island statewide Planning Program, State Land Use Policies and Plan, Report $\$ 22$, Jan. 1975, p.10

${ }^{14}$ University of Rhode Island, Rhode Island Resources Vo1. 24, No. 2, Fall 1977 p.3

${ }^{15}$ Rhode Island Department of Economic Development, op.cit \#6 p. 177

${ }^{16}$ U.S. Dept of Commerce, op.cit \#1 p.74

17 op. cit $\# 12$

18 op. cit \#6 p. 34 
19 Joseph Goodrich, "Low New England Wages jeen Attracting Business", Providence Evening Bulletin, Nov,, 10 1978

$20_{\text {Rhode Island Public Expenditure Council, Taxes on }}$ Business in 1976: Rhode Island Compared to 11 Competitor States, April 1977 p. 13

$21_{M}$. Charles Bakst, "Almond has plan to attract firms; Garrahy has a firm" The Providence Journal, Sept. 8, 1978 
KEY INDUSTRIES

\begin{abstract}
Within the Rhode Island economy there are a number of industries upon which the state's economy has traditionally relied or which appear to have extremely high growth potential. These are the industries upon which Rhode Island's economic future depends.
\end{abstract}

\title{
JEWELRY AND SILVERWARE
}

Rhode Island has what might be called a critical mass of jewelry industry. The agglomeration of jewelry firms allows these firms to draw upon a common labor force, attract a common market, subcontract tasks, and take advantage of a well organized trade association in Providence. 1 More of Rhode Island's total manufacturing emplorment is provided by the manufacture of jewelry and silverware than by any other industrial process. 2

As agglomeration provides advantages for individual industries, the presence of a critical mass of jewelry industries in Rhode Island gives the state a powerful attraction for foreign jewelry firms. Dr Gerhard Moog, quoted above, also cited among the reasons for Kienhoger and Moog's decision to build in Rhode Island, "Rhode Island is known as the state which does house the jewelry industry in North America." 3 Jewelry and silverware pro- 
duction is a key industry in Rhode Island. Its expansion can be of great importance to Rhode Island's economic future.

\section{SHIPBUIIDING}

Shipbuilding, particularly submarine construction, is one of the fastest growing industries in the state. The Electric Boat Division of General Dynamics at Quonset Point, which did not even exist five years ago, now employs approximately 5,400 workers, making it the single largest manufacturing firm in Rhode Island. 4 Expansion of this operation is still progressing with the construction of new facilities on recently obtained, former federal land. It will continue to be one of the mainstays of Rhode Island industrial development.

\section{FISHING}

Rhode Island's commercial fisheries are unique in New England in that they have thrived when other commercial fisheries have been declining. Rhode Island landings increased in tonnage by 110 percent and in value by 238 percent in the period 1950 to 1975 , a time when regional fisheries declined by 55 percent in tonnage and increased in value by only 74 percent. 5 Comercial fisheries generate an enormous amount of economic activity as compared with other industries. It has been calculated that, in 
Rhode Island, each $\$ 100$ in fish landings generates $\$ 424$ in economic activity. 6

As species management made possible by the new 200 mile U.S. fishing limit continues to encourage more and more fish landings in the state, revenue from this industry can continue to rise. At the present time, the Rhode Island fishing fleet obtains much of its equipment and engine servicing from New Bedford, Massachusetts and most of the catch landed in Rhode Island is frozen and shipped out of state for processing. This suggests that there may be considerable room for growth, not only in commercial fishing, but also in fishing support and marketing facilities in Rhode Island. Such expansion would help keep more of the economic activity generated by the industry within the state and make fishing a more important part of Rhode Island's future economy.

\section{ENERGY PRODUCTION}

With the nation's impending shortige of energy in the form of petroleum, the possibilites for production of alternative sources have become economically important. Development of energy sources in khode Island could be a major industry in the future. For example, construction of a proposed nuclear power plant in Charlestown, Rhode Island would generate considerable short and long term employment and economic activity in South County. 
The solar energy industry, which did not exist in 1973, was a \$150 million industry in the United states by 1977 and is still growing at an unbelieveable rate. 7 There are already fifteen companies of varying sizes which sell solar energy units in Rhode Island.

Probably the highest potential for economic development through energy production in Rhode Island lies in providing support to offshore oil and gas operations. Already there are thirty four companies within the Quonset Davisville complex in North Kingstown preparing for Outer Continental Shelf oil recovery operations. If a substantial find is made, these, and other related industries, could generate an estirated three to six thousand jobs for Rhode Island. 8 Energy production can make up a substantial part of Rhode Island's future economy.

\section{SHIPPING}

As mentioned in section IV above, long term import/ export patterns in the Port of Providence indicate an erratic pattern of slow net growth. Recent improvements to the Port, being undertaken by the City with federal funds, and labor dispute problems at other east coast ports, have begun to boost business in Providence very rapidly. By March of 1979 the City of providence had already taken in $\$ 1.6$ million in port fees as compared to about $\$ 900,000$ for the entire year in 1975-76, mostly because of a sub- 
stantial increase in the importing of steel. 9

The combination of the Port of Providence and Rhode Island's proximity to markets suggests that the state may be able to continue to boost shiping activities in the future, making import/export a major part of Rhode Island's future economy.

\section{TOURISN}

At the turn of the century, Rhode Island was known as "the playground of the rich". The wealthy came from all over the nation to take advantage of its cool sea breezes in the summertime. In this era, great mansions were built in Newport, huge wooden hotels filled with tourists in Narragansett, and Block Island earned the nickname "Bermuda of the north". Later on unfortunately, economic collapse and the great depression rulled the rug out from under the Rhode Island tourist industry. Lately it seems this industry has undergone an amazing revival. Media events like Operation Sail's "Tall Ships", which drew an estimated 150,000 visitor's to Newport, Rhode Island in one day in 1976, have again begun to spread the fame of Rhode Island as a tourist mecca. The state can undoubtedly capitalize on its natural resources to attract tourists and make tourism and important part of its future economy. 
OTHER INDUSTRIES

There are many other industries in which expansion has brought, and may continue to hring, economic improvement to Rhode lsland. Examination of new industrial construction in Rhode Island, bv industry, for the period 1967 to 1977 indicates that, during this period, average construction by all industries in which expansion occurred was 618.79 thousand square feet. In the same period, construction far above the average occurred in the following categories:

$\begin{array}{llll}\text { Nisc (includes jewelry) } & \text { SIC } 39 & 2471.9 \text { thou. } \mathrm{ft}^{2} \\ \text { Electrical Nachinery } & \text { SIC } 36 & 1540.5 \text { thou. } \mathrm{ft}^{2} \\ \text { Fabricated Netals } & \text { SIC } 34 & 1354.2 \text { thou. } \mathrm{ft}^{2} \\ \text { Instruments } & \text { SIC } 38 & 1219.2 \text { thou. } \mathrm{ft}^{2}\end{array}$

All other industries in which construction was undertaken constructed less than 680 thousand square feet of space. 10 Construction far above the average in the industries indicated above suggests that these are rapid growth industries in Rhode Is land.

It is interesting to note that two of these industries, electrical machinery production and production of instruments, are among the target industries chosen by Harbridge House, Inc. in a 1976 study of industrial and commercial marketability of surplus properties in Rhode Island. Based on detailed research, analysis, and survey results of U.S. industries' market characteristics, expec- 


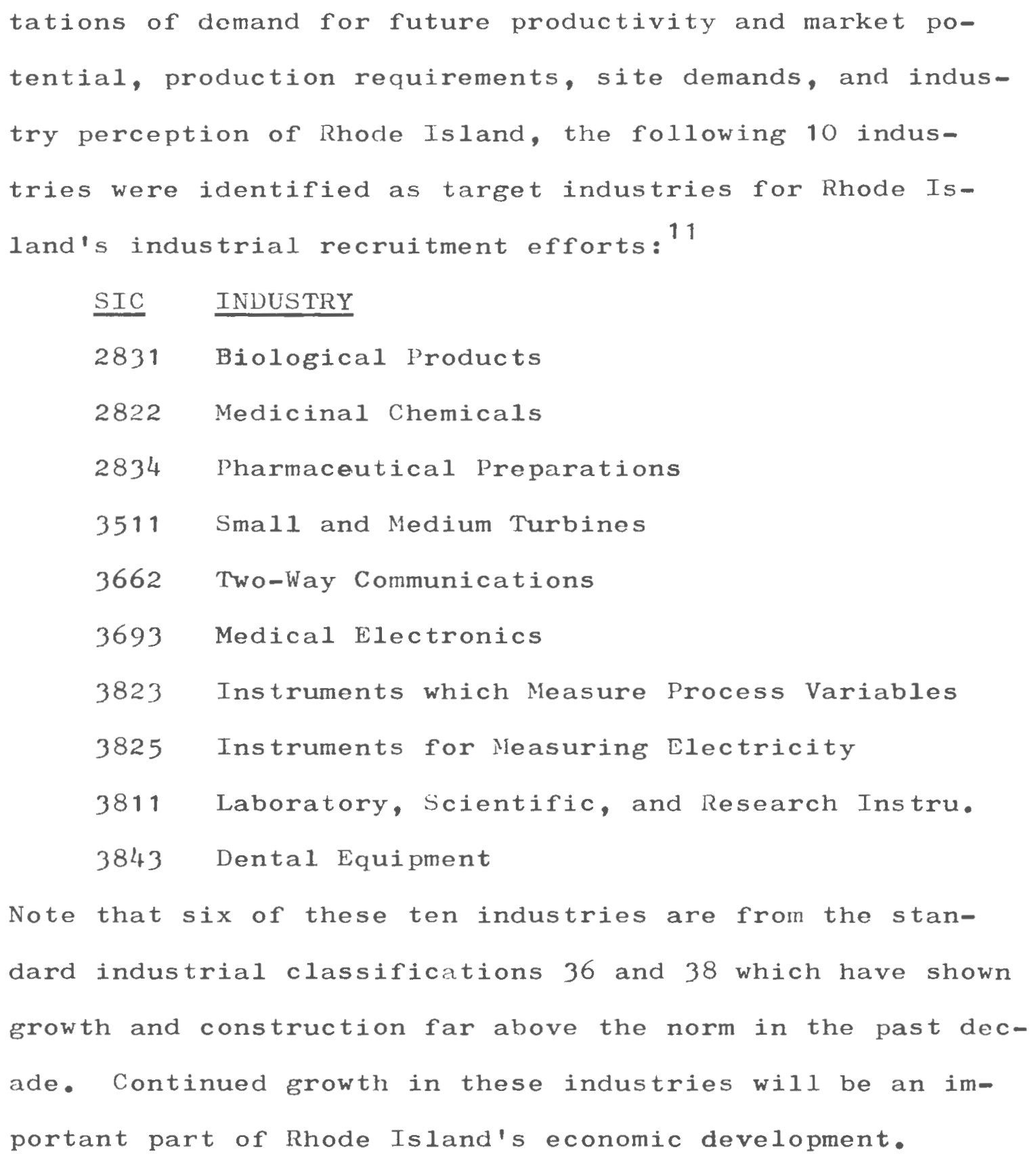


1 Steven lialton, "Location Dynamics and the Jewelry Industry in Rhode Island" (Mimeograph: 1977), p. 9

${ }^{2}$ Rhode Island Department of Economic Development, Rhode Island Basic Economic Statistics-The Economy, Summary and Trends, (Providence 1978), p. 24

$3_{M}$. Charles Bakst, "Almond has plan to attract firms; Garrahy has a firm", The Providence Journal, Sept.8, 1978

${ }^{4}$ Rhode Island Statewide Planning Program, Overa 11 Economic Development Program, (Providence, 1978), P.II-10

${ }^{5}$ U.S. Department of Commerce, N.O.A.A., State of Rhode Island Coastal Management Program and Final Environmental Impact Statement, March, 1978, p. 61

${ }^{6}$ Ibid

7 Anthony J. Parisi, "Profits from the sun" The New York Times, Sunday Apri1 30, 1978

${ }^{8}$ op.cit $\# 4$

9 Providence Evening Bulletin, "Fiat Selects Providence Port; 10, 000 Cars Due Annua11y" March 14, 1979

10 Op.cit $\# 4$ p. II -15

$11_{\text {Harbridge House, Inc. Industrial and Commercial }}$ Marketability of Surplus Properties in Rhode Island, April 1976, p. I -2 


\section{LINITING FACTORS}

After reading so many pages about Rhode Island's advantares, assets and resources the reader may begin to think that Rhode Island is the ideal place for economic development. There are two sides to every coin however and Rhode Is land economic development faces many serious limitations as wel1. This section is devoted to a discussion of these limitations and an assessment of needs for successful economic development.

\section{SHORTAGE OF INDUSTRIAL SITES}

While availability of land is one of Rhode Island's major assets, the advantages of this asset are in large part dampened by a lack of sites which are suitable for industrial development. A study done in 1972 indicated that, of the state's more than 22,000 acres of vacant land zoned industrial, less than $2,000(9.09 \%)$ could be classified as "prime", that is, equipped with good rail and highway access, sewers and water.'

$$
\text { Many sites are too small or are topographically un- }
$$

suitable for industrial development. Others are not close enough to major transportation routes, lack the necessary infrastructure for development or are located on prime agricultural land. In some c ses community leaders seem to 
have felt that industry should be located in areas which are not suitable for other uses, using the zoning classification "industrial" as a catch-all category. This has often resulted in the zoning of sites for industry which are not suited for industrial development. 2

Information about land in Rhode Island is often difficult to obtain. The Department of Economic Development has compiled an inventory of industrial sites but this is not computerized and not we11 maintained. It is important to have a comprehensive, dynamic listing of available sites in the state which can be kept up to date with relevant site information and can be readily accessed by development agencies for prospective investors.

Further, the state has no comprehensive land management policy. Land use control is the responsibility of individual towns, resulting in a variety of different attitudes toward land development in different areas of the state. Because of these factors, industrial development on specific sites is often handled in a piece-meal fashion. Persons who are familier with Rhode Island often cite former Navy land as prime land for future economic development. Much of this land is prime land. A great deal of this land is still owned by the federal government however and the federal government only permits it to be leased on a monthly basis. Few industries can be expected to expend large amounts of capital to develop land which is 
held on only a monthly lease. The state has mana;ed to successfully purchase several parcels of surplus federal land, particularly at Quonset loint in North Kingstown, but the price has been quite high and the state has a Iimited capability to afford purchases at similar prices. Lack of state control of these sites poses limitations on the expansion of submarine construction and oil support services currently considering these lands.

There is a need for:

-provision of infrastructure and preparation of suitable sites for industrial development.

-an up to date, dynamic inventory of available sites. -a statewide land management policy -more state control over surplus federal lands.

\section{INFRASTRUCTURE}

Rhode Island shares in a number of regional problems, one of which is an aging infrastructure characteristic of the mature economy of New England. Not only do sites often lack infrastructure, but many of the areas which are equipped with it are equipped with systems designed when Rhode Island was first industrialized. These are now old and inefficient, and sometimes no longer capable of fulfilling the functions for which they were designed. Rhode Island faces limitations due to its transportation systems, 
sewer systems, and water supply systems.

\section{TRANSPORTATION}

Among the most important infrastructure problems in Rhode Island are problems with the state's transportation systems, including roads and bridges, railroads, air service, and bay shipting. As the movement of goods and people is a crucial part of any economic activity, transportation problems pose serious limitations to all facets of economic development efforts.

Roads and Bridges

Since 1956,250 miles of new roads have been built in Rhode Island. 3 The state's major highways, including I-95, I-295, I-195, R.I. 195 and R.I. 146 are, for the most part modern highways in good condition. Route I-195 between Providence and East Providence has begun to deteriorate badly but repairs are currently under way. Route I-95 has been under construction somewhere along its length for most of the past decade but completion of this major route is expected within the next few years. While these major routes are well maintained with state and federal monies, Rhode Island's secondary roads have been continually deteriorating.

Several factors have combined to make driving on Rhode Island's secondary roads a jarring experience. 
First, the area's climate produces considerable freezing and thawing and generally a good deal of snowfall which makes plowing of roads necessary. These processes combine to break up pavement, leaving potholes and frost heave bumps.

Second, major sewer construction work which has resulted from the federal "208" water quality initiative has led many Rhode Island towns to dig up roadways for sewer construction. The result, while certainly improving the sewer situation, has made Rhode Island roadways a maze of detours and mudpits in many places.

Third, Rhode Island has no system of county government and thorefore no county roads. Roads which are not maintained by the state must be maintained by individual cities and towns which lack the revenue necessary for substantial renovation efforts. As a result sections of roadway in need of repavement often have to make do with patching. Less than satisfactory secondiry road surfaces can have an important negative effect on the state's economy. They can slow the movement of goods and people, cause unnecessary wear and tear to vehicles, and give visitors a bad impression of Rhode Island, thereby impeding tourist development.

There are other factors besides the condition of the road surfaces which offer limitations to development. Signage on Rhode Island roads is also often less than optimum. For example, the state contains two routes 195. 
Cne of these is Rhode 5 sland State route 195 which connects route I-295 with Rhode Island route 10 west of Providence. The other is federal interstate 195 which connects route I-95 with areas east of providence. These two routes do not connect. The similarity of their route numbers causes unnecessary confusion for persons unfamiliar with the state's highways.

Access to the larger islands of Aquidneck and Jamestown is provided over three major bridges, the Jamestown, Newport, and Mount Hope bridges. The Jamestown bridge, built in 1939, is no longer adequate to handle traffic which must cross it. Not only is the two lane, 22 foot wide bridge dangerously narrow but a recent inspection of the footings by a diver working for the state Department of Transportation has revealed erosion of concrete and raised some question as to the safety of this span.

There are other transportation problems pertaining to roadways which are not related to the age of these routes. The first is the lack of a suitable link between Rhode Island route 146 and the Massachusetts turnpike. At the present time, travelers on route 146 are guided to the vicinity of this major route in Massachusetts and then forced to find their way over secondary roads, mostly Mass, route 20 to gain access. Since the Mass. turnpike, I-90, is the major east-west artery for New England truck traffic, the inefficiency of this link is seen as a major factor limit- 
ing shipping along route 146 and consequentially limiting potential for development in this area.

The fact that vehicles have to travel to Nassachusetts to find a major east-west artery is a symptom of the lack of such an artery in Rhode Island, an important deficiency in the state's transportation network. At the present time, in order to travel west from Providence in Rhode Island vehicles must use route 6 , a secondary road. As a result, commercial linkages between providence industries, and the Port of Providence, and points west such as Hartford, Connecticut, another major industrial center, are limited. Development of a major east-west artery would help to connect Rhode Island with western markets which are currently underexploited.

There is a need for:

- improvements to secondary roads in the state.

- replacement of the Jamestown bridge.

- improved signage on Rhode Island roads.

- an improved linkage between route 146 and I-90 in Mass.

- construction of a major east west linkage between Providence and Hartford, Conn.

Railroads

Rail service in Rhode Lsland is provided by five private rail lines, the Providence and Worcester railroad, Mo- 
shassuck Valley railroad, Warwick railway, Sea View railroad and the Narragansett pier railroad as well as the federal Consolidated Rail Service (Conrail). Passenger service is provided by Amtrack. Once one of the principal means of transportation for Americans, railroads have experienced continued decline during the past few decades. Continued subsidies for trucking and automobile transportation in the form of highway construction have spelled disaster for many railroad companies. Unable to capture enough of the shipping market to operate profitab1y, these companies are forced into bankruptcy. Railroad earnings are only three-quarters of their 1947 level even after adjusting for inflation and the state's rail lines, once consisting of over 185 miles of track, have been reduced to 135 miles, or less than $75 \%$ of the original system. 4

Facilities and equipment have, for the most part, not been properly maintained, contributing to decline. Passenger service is not cost competitive with other modes of travel and trains rarely run on time. The state has recently had to stop subsidizing commuter service to Boston from Providence as it was proving too costly for the service provided. The state had been paying $\$ 467,000$ for an average of 300-350 passengers daily, nearly $\$ 1,300$ per person in 1978 and indications were that the same service would have cost as much as $\$ 632,000$ in $1979 .^{5}$ 
Although Conrail has begun a major improvement project on the mainlines through Rhode Island, secondary lines continue to deteriorate. Others have been or are being abandoned. While many industries obviously do not use rail service as evidenced by the decline of railroad revenue, many industries do. In a study of the marketability of abandoned Navy property in Rhode Island, Harbridge House Incorporated states:

"Several of the industries identified in the marketing program for the re-use of the Naval bases do have specific rail requirements for shipment of their materials or products. These industries would be lost to the State's marketing efforts in those areas where rail access was not available.... Clearly, rail access is an important element in some industries' location needs, and even where rail isn't essential its availability suggests the kind of industrial characteristics that industries typically look for."6

As energy in the form of petroleum, particularly diese1 and gasoline, becomes more and more expensive during the next few decades it is probable that Rhode Island may again come to rely on some form of rail service. Even if there are significant changes in technology, the rights of way over which rail lines pass may prove very valuable for some other form of mass transit. Loss of these may place unnecessary limitations on economic development efforts.

There is a need for:

- preservation of existing and recently abandoned rail 
lines in the state.

-maintenance and repair of existing secondary rail 1 ines. -provision of fast, clean, efficient and cost competitive commuter rail service.

Air Service

There are five general aviation airports in the state of Rhode Island. Major passenger and freight service is out of T.F. Green State Airport in Warwick. This airport and its service, is one of the state's major limitalions. It is not a very large airport; in 1977941,550 scheduled passengers and $16,709,0001 \mathrm{bs}$ of cargo flew from Green, nor is it an international airport. 7 passengers must fly to New York or Boston for international service. Because Boston's Logan airport is slightly more than an hour's drive from Providence, one out of three passengers from the Providence area uses Logan Airport instead of Green, costing Green 1.2 million passenger trips and $\$ 75$ milion in fares annua 11 . 8

One of the reasons for this is the airport facilities at Green. Green is far from being a modern airport. There is a scarcity of parking, there are no enclosed gates, passengers must walk across taxi-ways to board planes, and the runways are too short to accomodate large modern aircraft. Baggage claim procedures are less than adequate also as claim checks are rarely examined by of- 
ficials. In short, the airport does not speak well of Rhode Island to business persons who use its facilities and is not a convenient, easy to use facility. As a result, in 1978, when de-regulation provided airlines with an opportunity to stop flying to Green, National Airlines and Eastern Airlines took advantage of it and cut all flights to Green. The departure of these airlines has placed the airport in a precarious position as it may trigger a self reinforcing trend toward further reductions of air schedules. 9

Travelers tend to seek out those routes where the most frequent service is avilable and shun those with infrequent service because of the inconvenience of infrequent service. Lack of passongers leads airlines to cut back on service, increasing the inconvenience and so on. Such a self reinforcing trend could send so much of Rhode Island's traffic to Logan that it would leave Rhode Is land virtually without major air service. This could have disastrous results for economic development.

There is a need for:

- major renovation of the facilities at Green State Airport to meet requirements for loading and baggage claim, provide more parking, and accomodate large, modern aircraft. 
Bay Shipping

Most of the commercial shipping in Narragansett Bay enters and leaves through the port of providence. The Port of I'rovidence is at the head of Narragansett Bay and includes both sides of the upper bay in l'rovidence and East Providence. This port has 4,750 feet of berthing space, 265,000 square feet of shed storage space, and 45 acres of open storage yard. ${ }^{10}$ It is one of New England's major shipping centers for petroleum products, imported automobiles, lumber, and scrap iron.

The Providence River channel has been dredged by the Army Corps of Engineers to a control depth of 40 feet. Unfortunately, this dredging did not include much of the berthing space in the harbor. Further dredging is needed to accomodate increasingly larger vessels in use today. ${ }^{11}$ The problem of how to properly dispose of dredge spoils is a very serious one. Bottom sediments in the Providence River are heavily polluted with oil, heavy metals, and other toxic chemicals. Ocean dumping could be detrimental to marine organisms and the fishing industry. Land disposal could have similar conseruences for terrestrial ecosystems and can be prohibitively expensive.

There is a need for:

- further dredging in the Providence River to increase berthing and anchorage space. 
- research to determine the best means of disposing of the spoils of such dredging.

WATER SUI'PLTES

Although Rhode Island is blessed with an abundance of fresh water, this water is not always where it is noeded most. It is also not all of suitable quality for public water supnlies. Because of this, treatment plants and supply lines are necessary to provide running water for public use. These are provided by numerous state, and private, water systems.

The State l'lan for the Development and Use of Public Vater supplies has indicated that, most of the major systems in the northern, central and south-eastern part of the state will be unable to meet projected needs by the year 1990.12 Rhode Island's abundant rainfall will be a virtually useless resource if it cannot be stored and de1 ivered to where it is needed.

The last major drought in Rhode Island occurred in 1965. Since then, Rhode Islanders have all but forgotten their temporary concern for water supplies. A referendum for work on a new reservoir in West Greenwich, Big River Reservoir, which would provide water for the metropolitan areas of the state, was soundly defeated in 1978 balloting. It seems Rhode Islanders assume that, because the state 
has abundant rainfall, water supnlies must be adequate. They do not seem to make the distinction between water and water supply systems.

There is a need for:

- an increase in water supply, storage, and delivery capacity to meet projectod needs for Rhode Island.

- informing the public of the potential deficits anticipated for specific water supply systems and the consequential economic effects of these deficits.

SEWERS

Sewers in Rhode Island have recently received a great deal of public attention due to the scattering of what were euphemistically termed "grease balls" on Narragansett Bay shores from the lrovidence and lawtucket sewage treatment facilities. At the present time, the sewage treatment facility in Providence is completely non-functional. Efforts to repair this system are currently under way but are not expected to be completed until Novembor of 1979. This means that, throughout the summer tourist season the city of Providence will be dumping raw sewage into Narragansett Bay at the rate of 54,000,000 ga1lons per day. ${ }^{13}$ It is unrealistic to assume that this will not affect the tourist industry in Rhode Island.

$$
62 .
$$


In addition, because of the heavy metals, toxins, acids, and pathogens contained in these sewage discharges irreparable damage is being done to marine food species, particularly shellfish. This of course has detrimental effects on the Rhode Island fishing and shellfishing industry and precludes aquaculture in the upper part of Narraganett Bay.

Providence is not the only deficient sewage system in Rhode Island however. Of 14 municipal wastewater treatment facilities operating in the Rhode Island 208 planning area, six provide only primary treatment, a process which consists only of heavy sludge removal, before chlorination and discharge. ${ }^{14}$ One community besides Providence, the town of Jamestown, discharges raw sewage directly into the bay.

Other problems arise because many of the urban systems in the state are designed to handle storm water runoff through the same lines which handle sewage. Is a result, at times of major rainfal1, these systems are overloaded and spill untreated sewage into rivers or the bay. To be fair, it must be noted that, of the systems which provide only primary treatment, all six have begun construction or plans to correct these deficiencies. Even the town of Jamestown has begun to construct a treatment plant. In the meantime however, discharges into Rhode Is- 
land waters continue to diminish their value for residents and tourists and have effectively eliminated shellfishing in much of Narragansett Bay.

There is a need for:

- expeditious completion and implementation of the Rhode Island Areawide Water Quality Management Plan particularly with regard to the Providence treatment facility.

\section{ENERGY}

Rhode Island, like most of New England, is at a competitive disadvantage in terms of energy costs. Table III helps indicate the extent of this disadvantage. There are a number of factors which contribute to Rhode Island's and New England's, energy problems. First, this region is at the end of most native energy pipelines. That is, the region is not a major producer of energy. Energy comes to New England from other regions and is then consumed. It does not, for the most part, originate in New England but is consumed here.

Second, New England is very dependant on imported petroleum products for its energy. ${ }^{15}$ Because of this, continued price increases by petroleum exporting nations have a more serious impact on New England than on other regions. This also makes New England particularly vulnerable to in- 
TABLE IIT

Energy Costs, New England vs United States

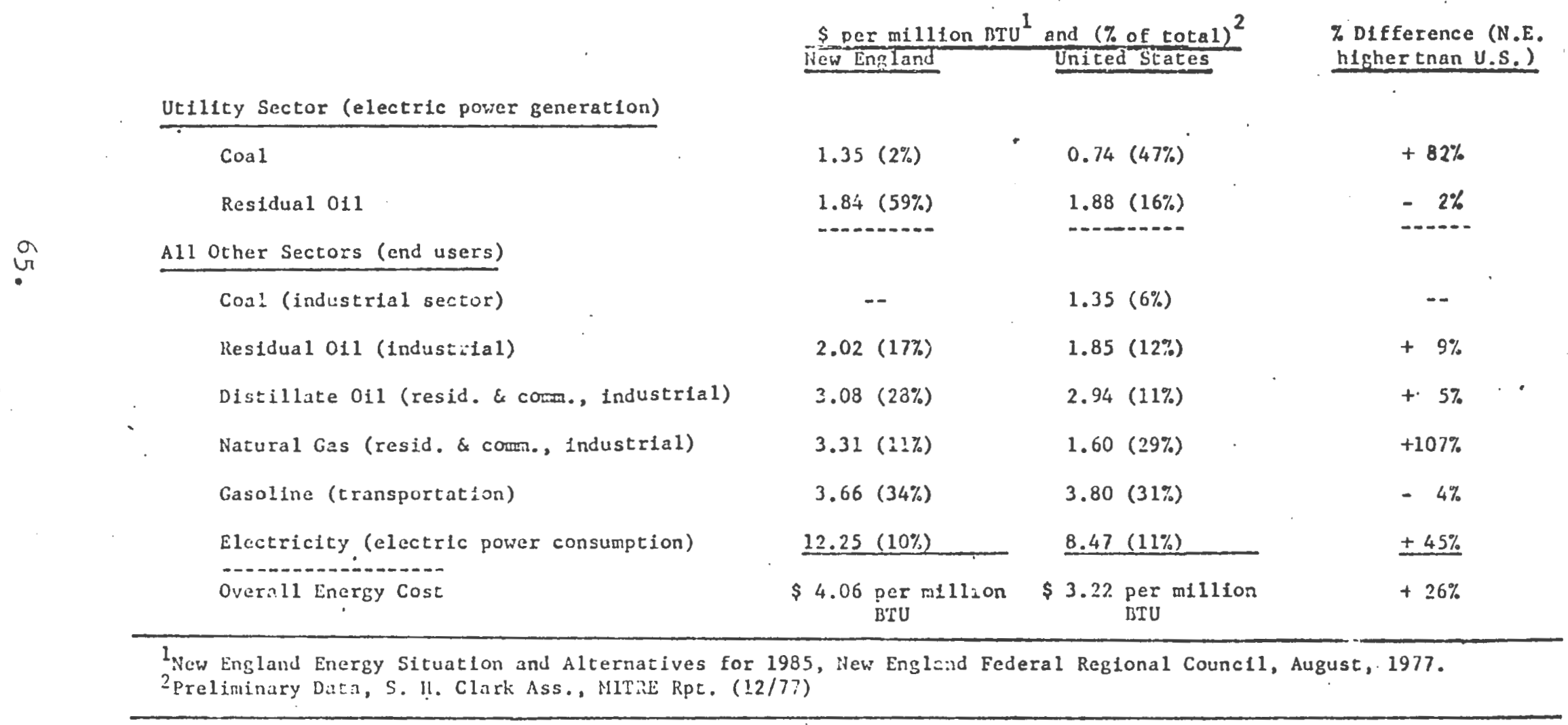


terruptions in foreign oil flow due to political instability in oil producing nations.

Last, the climate in New England is such that large amounts of energy must be expended to keep residences and businesses comfortable room temperature. Rising energy costs therefore cause parallel increases in fixed cost of home and business operation. These are costs that can be avoided by moving to warmer regions.

Equally important as a limitation to economic development is the recognition that world supplies of energy, in the form of petroleum, are fast dwindling. While the effect of diminishing supplies of oil cannot, as yet be quantified, it seems reasonable to expect that prices will continue to rise and availability will continue to decline further complicating New England's energy problems.

The discovery of major oil and gas deposits off the New England coast may help to imrove the energy situation for Rhode Island but does not represent a solution to all its energy problems. Also such deposits have not yet been proven and therefore should not yet be relied upon. Even if substantial finds are made, relief would be only partial.

Due to limited refinery capacity in the Northeast, sources indicate that oil found offshore would be sent to Middle Ntlantic refinerys for processing. This means that 
New England would stand to benefit only through supplying support services to offshore drilling operations and through exploitation of natural fas. At best offshore oil and gas can only postpone the critical stage in New England's energy problem.

There is a need for:

- development of alternative energy sources to petroleum.

- an easing of New England's dependance on foreign oil.

- action by New England states to urge greater equity in the distribution of energy costs nationally.

- increased oil support capacity in New England to handle offshore oil if and when it is discovered.

FEUERAL REGULATIONS AND SMALL BUSINESS

Federal regulations, advancer and enforced by such federal agencies as the Occupational Safety llazards Administration $\left(\mathrm{OSH}_{x} \mathrm{\Lambda}\right)$ and the Environmental J'rotection Agency (EPA) can have a profound effect on small business. They may threaten its very existance as many small, marginal firms cannot afford the costs imposed br these regulations. 16 Because of the predominence of smal1, marginal firms in some Rhode Island industries, such as the jewelry industry, these regulations can have a disastrous effect on the Rhode Island economy. 
For example, the Federal Water Pollution Control Act as amended in 1972 requires pre-treatment of certain discharges from industries into public waste treatment plants. Approximately 3,100 industries in the 208 water quality management area could be affected by these pre-treatment standards. 17 It is not known how many of these firms will experience economic difficulty with meeting these standards. It is reasonable to assume however, that many marginal jewelry firms of small size ongaged in such operations as electroplating, which involves caustic acid and heavy metal discharges, will be unable to afford costly equipment needed to treat these effluents.

Similar problems occur with OSHA requirements, particularly those which pertain to building codes. Many Rhode Island jewelry firms operate in former textile mills built as much as a century ago. In some cases these firms cannot justify the expense involved in bringing these facilities up to federal standards.

There is a need for:

- a state operated assistance program to aid firms in finding cost effective means of meeting federal standards. 
UNENI' OYMENT COM'ENSATION TAX

Another factor which impedes Rhode lsland's efforts at economic development is the state's unemployment compensation tax which is unusually high. 11976 study of comparative tax burdens in 12 competing locations having roughly the same economic characteristics found that Rhode Island's unemployment compensation tax was the highest of al1 location studied. ${ }^{18}$ Since assessment of competitive tax burdens is an important part of most firm's location processes, the existence of this higher tax can place Rhode Island at a competitive disadvantage in its efforts at firm attraction.

Considerable rhetoric has been generated attributing Rhode Island's unemployment compensation tax problems to the State's policy of making unemployment compensation benefits available to strikers. At the present time, Rhode Island is one of only two states where this is permitted.19 The other state is New York. Those who oppose the payment of these benefits point out that Rhode Is 1and seems to be in somewhat of a unique position and suggest that the practice gives the state a bad image in the eyes of business.

While it may be the case that unemployment compensation benefits to strikers generates a negative impression in the eyes of business, there is no evidence to indicate 
that there is any connection between the existance of this bonefit and longer or more frequent strikes in Rhode Island. 20 Further, since strikers must continue a work stoppage for at least seven weeks to qualify for benefits, and most of Khode Island's strikes are settled before the expiration of this time period, cost to the state from unemployment compensation to strikers has been insignificant. These have amounted to a little over $1 \%$ of benefits paid out since 1938 according to Mary Hackett, director of the Rhode Island State Department of Employment Security. 21 A recent study done by professors at Bryant College concluded: "Since the payment of unemployment benefits to strikers has little or no impact on labor costs, we conclude that it has little or no impact on potential investor's location decisions in Rhode Island."22

Far greator problems have resulted from the state's practice of making unemployment compensation available to persons who voluntarily leave the work force, particularly retirees. This practice is, in large part, responsible for the state's high unemployment compensation tax. Its cost has amounted to some $\$ 8$ million annually and has been a major contributor to Rhode Island's \$101.9 million dollar deficit in the jobless fund. Because it has been paying out more in benefits that it has been collecting in tax revenues, the state has had to borrow from the Federal Government to make up the jobless fund deficit. 


\begin{abstract}
In order to reclaim monies lent to the state for unemployment compensation, the Federal government has imposed an annual incremental tax on employer payrolls which continues to increase by three tenths of one percent until the deficit is repaid. This tax is superimposed on Rhode Island's already high unemployment compensation tax. This can not only place a damper on Rhode Island's firm attraction efforts, it may encourage firms to leave the state. There is a way out however. If the state can demonstrate that it is making an attempt to pay back the borrower money it can qualify for a deferment of the rederally imposed tax. 24
\end{abstract}

There is a need to:

- restore solvency to the Rhode Island jobless fund through state imposed taxes, at reasonable levels, on business. - ensure that benefits from the fund do not bankrupt it again by tightening elegibility requirements, particularly those for retirees.

\title{
UNSKILLED LABOR
}

As indicated in section II, skill and education levels among mombers of the work force in Rhode Island tend to be lower than in surrounding areas. This is particularly true of unemployed persons. Limited skill and education could lead to problems with hhode Island economic develop- 


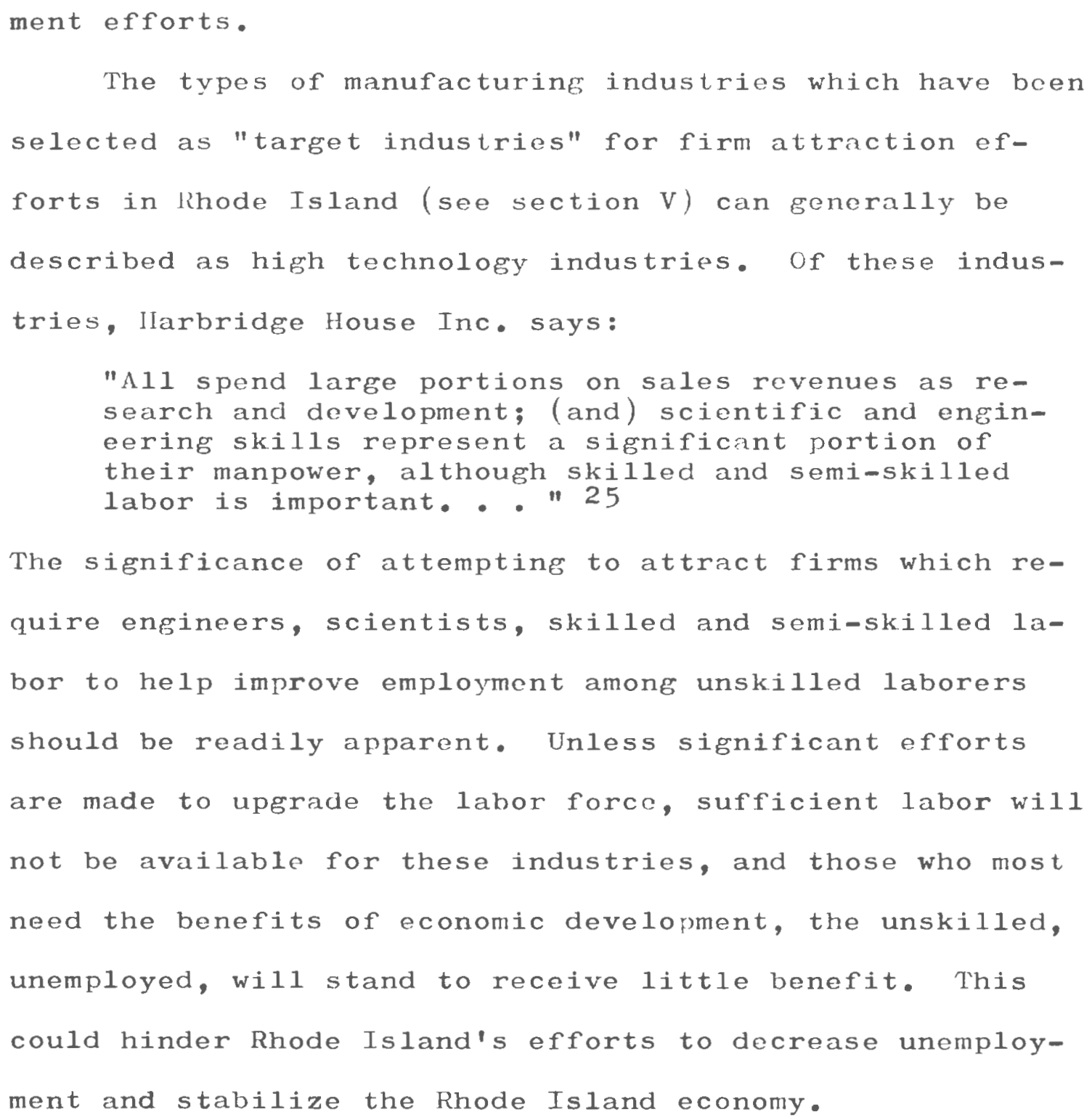

There is a need for:

- continued and renewed efforts to upgrade the labor force in Rhode Island.

\section{FACILITIES}

There are two key industries which will require new 72 . 
or expanded facilitics in order to continue expansion, the tourist industry and the fishing industry. At the present time facilities in the state are inadequate to support much expansion of either.

TOURISM

With regard to tourism, the statewide Planning Program's report number 33, on economic development, cites "deficiencies such as the lack of a complete resort facility in the state..... and the need for current motion picture films to advertise the vacation potentials of areas" as limiting factors. 26 In addition, Rhode Jsland has no large convention center, an important facility for maintaining tourism through the winter months.

There is a need for:

- construction of a convention center and/or resort facility, by private investment, to attract and accomodate tourists.

- an intensive publicity campaign to advertise the merits of Rhode Island as a vacation center.

COMMERCIAL FISHTNG

Lately commercial fishermen have received a great deal of attention in lhode Island by banding together to demand more support from state government. Principal a73. 
mong the problems they have cited has been probloms over dock space. In crowded harbors where many types of boaters must share space and competition for dock space is steep, fishermen do not always fare well. Often they are unable to compete with pleasure boaters who do not depend upon dock space for their livelyhood and yet can sometimes afford to pay more for dockage than fishermen.

Further, fishermen require considerable on-shore space for loading and unloading operations, clearing cables and nets, and storing equipment. This is often hard to find in the immediate vicinit of a harbor where land values are at a premium.

Space is not the only problem facing the Rhode Island fishing industry. If this industry is to continue to expand there also must be an increase in support ficilities for fishermen in the form of engine repair and servicing, parts and equipment supply, markets, and processing plants. Without these, much of the revenue generated by Rhode Island's fishing industry will be lost to other areas.

There is a need for:

- continued state and local assistance to fishermen in obtaining and keeping dock space.

- expanded on-shore support facilities to "capture" more of the indirect economic activity generated by commercial fishing. 
1cademy for Contemporary Problems. Revitalizing the Northeastern Economy. Columbus: The lcademy for Contemporary Problems, 1977

Allen, llamilton "Green Loses :Hllions to Logan" Providence Evening Bulletin, Ipril1 10, 1979

Bakst, H. Charles. "Almond has plan to attract firms; Garrahy has a firm" The l'rovidence Journal, Sept. 8, 1978

Calitri, Vincont. R.I. Department of Imployment Security. telephone interview Tuesday, Nov. 14, 1978

DeRoos, Robert. "Rhode Island, New England's 'I ively Experiment'", Nat'1 Geographic Nagazine. Sept. 1968

Feld, Marcia $\because$. and Milburn Josephine F. Workshops on Citizen Participation in Rhode Island. Providence: The Rhode Island Committce for the Ifumanities, 1976

Goldstein, Gerald S. "R.J. Plans 2.5 million to devolop fishing port". The Providenco Journal, March 22, 1979

Goodrich, Joseph. "Low New lngland Wagos seot httracting Business", Providence Evening Bulletin, Nov.,10 1978

- "Will small business be out of business by the year 2000?". The Providence Journal, Nov. 12, 1978

Grass-Roots, Providence. October 1, 1977

Harbridge llouse Inc. Industrial and Commercial Marketability of Surplus roperties in Rhode Island. Boston: Harbridge House Inc. 1976

Hsi C. Li and Ilacqua, Joseph A."Economic and Psychological Costs of Unemployment Compensation Benefits for Strikers to lotential Investors in Rhode Island" (Nimeographed) 1977

The New York Times, May 25, 1977

l'arisi, Anthony J. "l'rofits from the sun" The New York Times, Sun. Apr. 301278 
Providence Evening Bulletin, March 21, 1979

- "Fiat Selects l'rovidence Port; 10,000 Cars Due Annually" March 14, 1979

Reid, David. "Steelworkers to ignore Governor's Partnership" The Providence Evening Bulletin, Oct. 17, 1978

Rhode Island Department of Liconomic Development. Rhode Island Basic Economic Statistics-The Economy, Summary and Trends. Providence 1978

- Rhode Island n.d., n. 1. Providence

- "Rhode Island: Its Opportunities Can't be Measured in Square Miles". Forbes, May 15, 1977

Rhode Island Public Expenditure Council. Taxes on Business in 1976: Rhode Island Compared to 11 Competitor States. Providence 1976

Rhode Island Statewide l'lanning Program. Job Need in Rhode Island, Estimating the Number of Jobs Needed 19701985 Technical Paper Number 72. J'rovidence 1978

- Rhode Island Overall Economic Development Program. Providence 1978

- Plan for the Development and Uso of Public water Supplies. Report Number 10. Providence 1969

- Rhode Island Arearide Water Quality Management Plan. DRAF' COPY l'rovidence 1978

- Rhode Island State Rail Plan Report Number 31, P'rovidence 1977

- Rhode Island Transportation Plan - 1999 Report Number 19. Providence 1973

- State Land Use Policies and Plan, Report Number 22. Providence 1975

- Toward A Comprehensive Economic Development Strategy for Rhode Island. Report Number 33 DRAFT COPY Providence 1977

Save the Bay, WEAN Radio, Lpril 8, 1979 
Scanlon, Christopher. "Threat of cutback in railroad service spelis bad news for R.I. commuters". The l'rovidence Journal, Nov. 12, 1978

Schlesinger, J.A. "The Politics of the Dxecutive" in llerbert Jacob and K. $N$. Vines, Edts, l'olitics in the American States. Boston: Little Brown \& Co. 1965

United states Department of Commerce, Bureau of the Census. Area Measurement Reports, GE-20, No. 41, Apr. 1967

- Characteristics of the J'opulation. Vo1. 1, Part 41, "Rhode Is land" Waslington 1970

- "Current Iopulation Reports, Topulation Istimates and Projections". Series I'-25, No. 778, Jan. 1979

United States Department of Commerce, NOAA. State of Rhode Island Coastal Management Program and Final Lnvironmental Impact statement, Washinoton 1978

University of Rhode Island. Rhode Island Resources Vol. 24 no. 2. Fall 1977

Walton, Steven. "Location Dynamics and the Jewelry Industry in Rhode Is 1and" (Mimeographed) 1977 
IMAG

Rhode Island appears to have an inage problom. Rhode Islanders seem more willing to discuss the state's limitations and problems than to mention its assets. Certainly the state's problems are many but its assets are also numerous. Perpetuation of negativeism can be severely detrimental to efforts at firm attraction and tourism, and encourages discouragement.

This problem is further complicated by the perpetuation of numerous myths which detract from the image of the state. In spite of evidence to the contrary, Rhode Island is often charecterized as a labor state where frequent strikes of long duration occur, and as a high wage state with high business taxes and low worker productivity

Nuch of this reputation is not based in fact. For example, the idea that Rhode Island workers exhibit low productivity is a result of the use of value added figures as an indicator of worker productivity. Rhode Is land's figures for value added per man hour are considerably lower than those of its neighbors. ( see table IJ, page 11.) But value added is not a good indicator of productivity. Rhode Island, with its emphais on low value added production, and an older, less efficient industrial base cannot be expected to exhibit the same value added figures as other, more recently industrialized, areas. 
Taxcs, discussel under assets in section III are not unusually high in Rhode lsland. With the exception of the unemployment compensation tax they ar quite low. Taken as a whole, taxes are lower in Providence Rhode Island than in many other similar industrial areas. 27

As for labor disiutes, Table TV (following page) shows that Rhode Island's labor dispute record is superior. In the six years from 1971-1976, Rhode Island's proportion of work time lost to disputes was $13 \%$ below the national average, and the percentage of private, nonagricultural workers in-volved was only 76\% of that for the United States.

Analysis of data such as this helps to show that much of Rhode Island's bad reputation is undeserved. The perpetuation of negative myths instead of positive realities contributes to Rhode Island's image problem. It is time Rhode Islanders viewed their state with a little bit of pride.

There is a need for:

- intensive publicizing of Rhode Island's numerous attributes both inside and outside the state.

GOVIIRNMENT LIMITATIONS

Despite the numerous advantages of Rhode Island's Government approach to economic development there are cer76. 
T A B L E IY

LABOR DISPUTE RECORD: 1971-1976

\section{INDUSTRIAL STATES AND THE UNITED STATES}

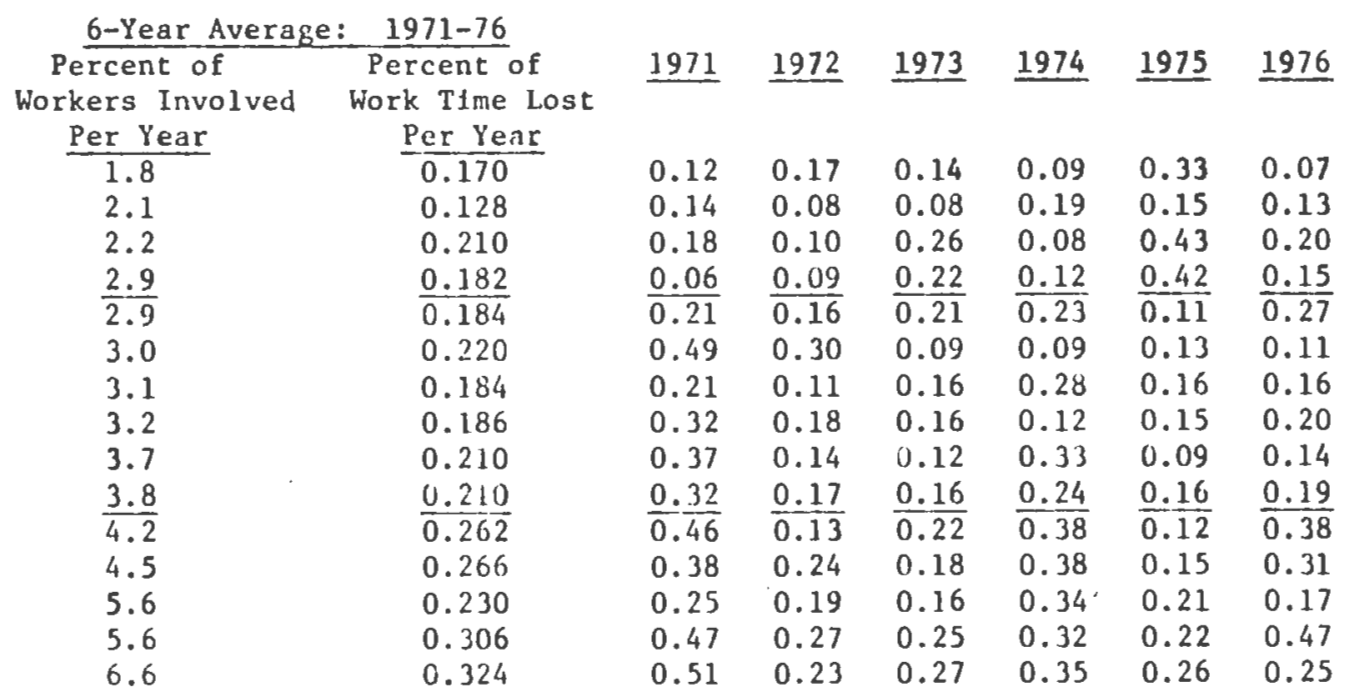

Source: U.S. Department of Labor 
tain charecteristics of the government which tond to inhibit economic devclopment efforts. These include problems with citizon participation, lack of goal conconsus in intergovernmental relations, and the two year term of office of the Governor.

\section{CITIZEN PARTICIPATIUN}

It is unfortunate that citizen participation in modern public affairs scoms most often to be negative in nature. Citizens feel left out of the decision process until decisions have been made. As a result, citizen participation is often manifested in negative or "anti" groups. Some Rhode Island examples of these are Stop I-84, a group dedicated to preventing construction of a major east-west artery through Rhode Island, and the Rhode Island Clamshell Alliance, a group determined to prevent construction of nuclear power plants in the state.

In the late 1700 s and early 1800 s citizens participated directly in government. Decisions were made in town meetings and citizens were involved in both local and state issues. In the nineteenth century, the structure of decision making underwent changes which resulted in decisions being made in councils rather than in meetings of the citizens. 29 As a result, citizens are often not involved in decision making but are informed of decisions already made, a fact which tends to generate animosity among 78. 


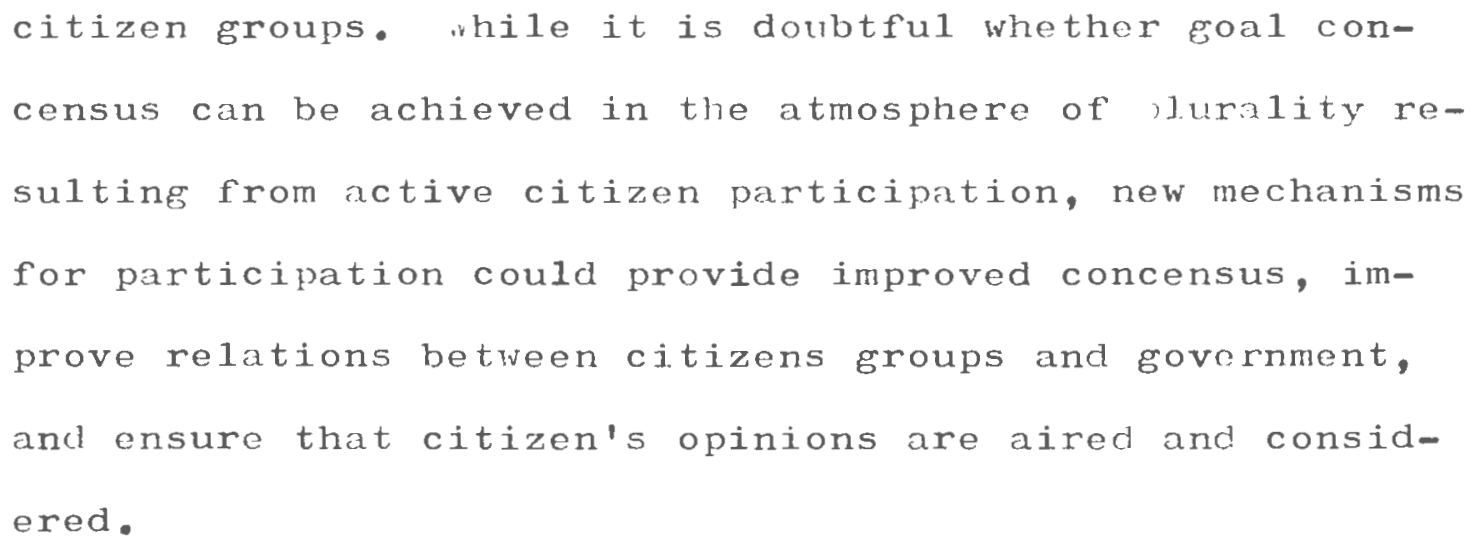

There is a need for:

- stronger mechanisms for citizen participation which involve citizens early in the decision making process.

\section{INTEIRGOVLRNMLNTAL RELATIONS}

Rhode Island, for a11 practical purposes lacks a county level of government. There are only two levels of jurisdiction, State and local, in Rhode Island. The absence of sub-state government is not surprising in view of the small size of the state, but it necessitates direct interaction between town and state government. Unfortunately, there is often a lack of goal concensus between these levels of government. For example, certain lowns do not favor growth and development or favor slowing growth. As a result, these towns work against State economic development efforts and impede their progress.

Again, as is the casc with citizen participation, 


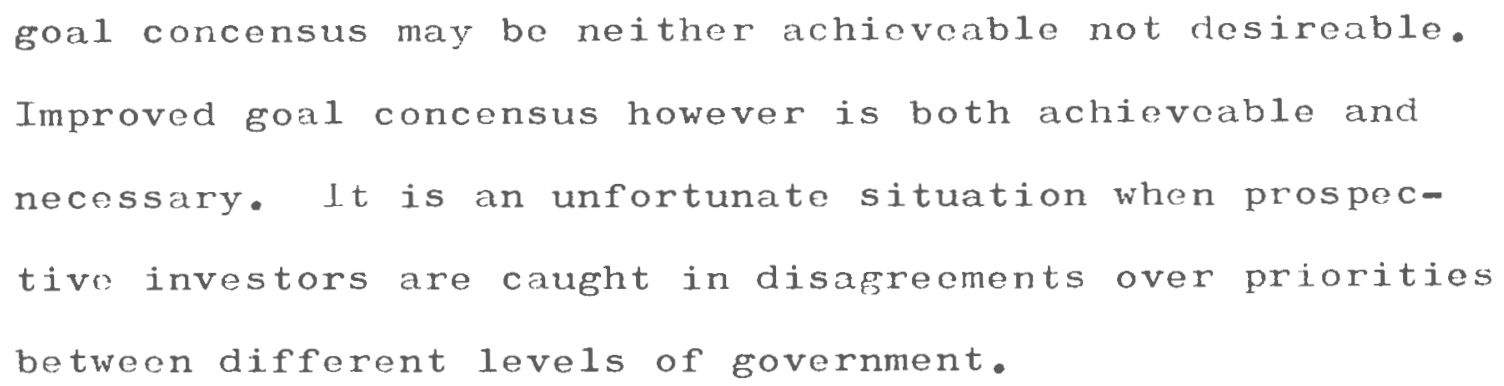

There is a need for:

- improved sensitivity of state government to local development priorities and vice versa.

GOVERNOR'S TFRM GF OFFICE

There is a fundamental weakness in the structure of State government in Rhode Island in that the Governor's term of office is only a two year term. The Governor is the driving force behind economic development in Rhode Is1and. The short term of office limits his ability in several ways.

First, since the fiscal year and the Governor's term of office do not coincide, the Governor must spend a substantial part of his first two year term operating on a budget designed by his predecessor. This limits his control over State government agencies. Second, a new Governor must spend a large part of his first term bccoming acquainted with the intricacies of his office. By the time he has begun to gain an understanding of his office and established sufficient control to take 


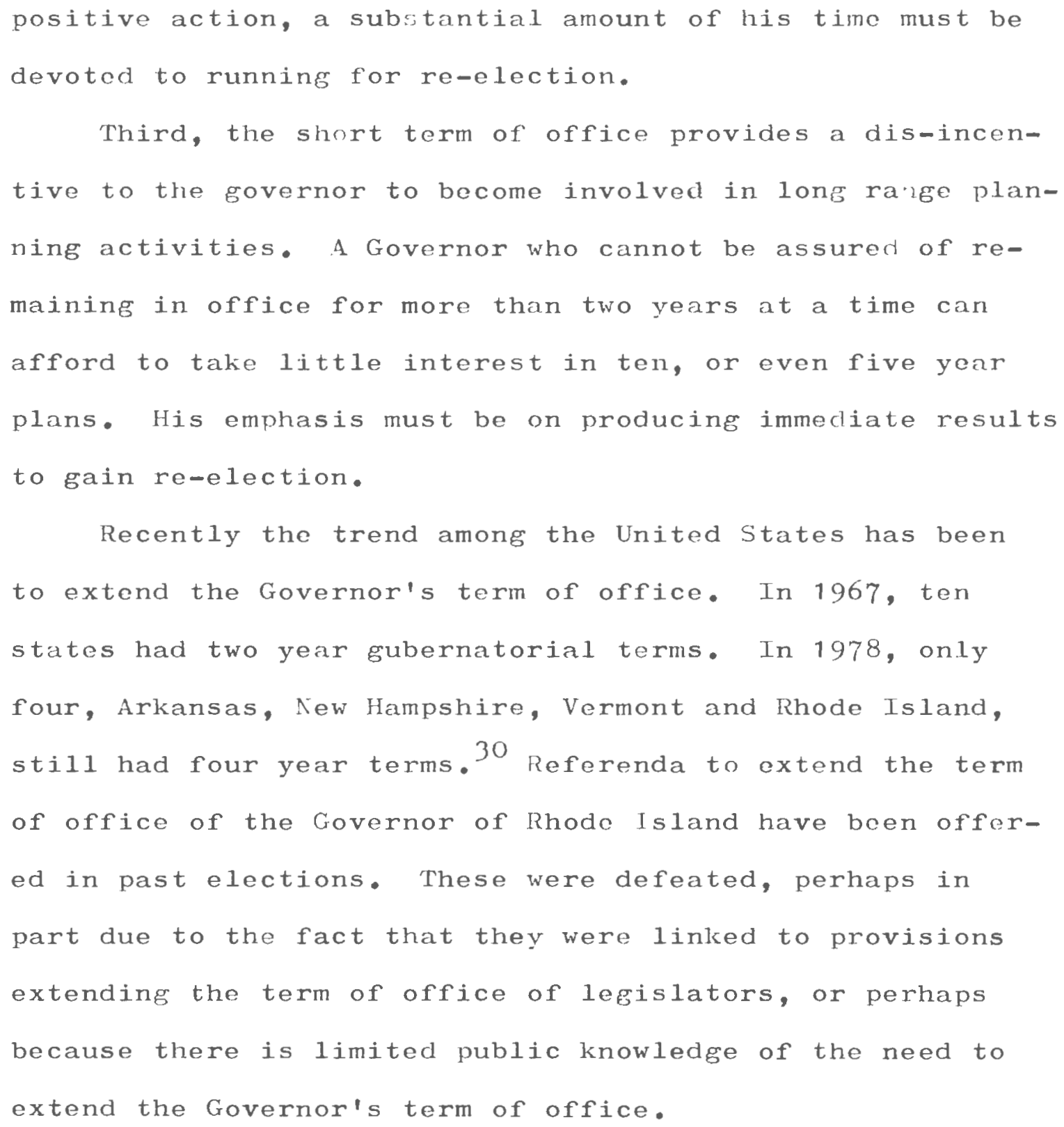


$\underline{\text { LAND }}$

There is a need for:

- provision of infrastructure and preparation of suitable sites for industrial development.

- an up to date, dynamic inventory of available sites.

- a statewide land management policy.

- more state control over surplus federal lands.

INFRASTRUCTURE

TRANSPORTATION

Roads and Bridges

There is a need for:

- improvoments to secondary roads in the state.

- replacement of the Jamestown Bridge.

- improved signage on Rhode Island roads.

- an improved 1inkage between routes 146 and I-90 in ilass.

- construction of a major east west linkage between Providence and Hartford, Conn.

Railroads

There is a need for:

- preservation of existing and recently abandoned rail lines in the state.

- maintenance and repair of existing secondary rail 1 ines.

- provision of fast, clean, efficient and cost competitive commuter rail service. 
Air Service

There is a need for:

- major renovation of the facilities at Green state $\Lambda$ irport to meet requirements for loading and baggege claim, provide more parking, and accomodate large, modern aircraft.

Bay Shipping

There is a need for:

- further dredging in the l'rovidence River to increase berthing and anchorage space.

- research to detormine the best means of disposing of the spoils of such dredging.

WATER SUP'PLIES

There is a need for:

- an increase in water supply, storage, and delivery capacity to meet projected noeds for Rhode Tsland.

- informing the public of the potential deficits anticipated for specific water supoly systems and the consequential economic effects of these deficits.

SEWERS

There is a need for:

- expeditious completion and implementation of the Rhode Is land Areawide Water Quality Management Plan, particularly with regard to the Providence treatment facility. ENERGY

There is a need for: 
ENERGY (continued)

- dovelopment of alternative energy sources to petroleum.

- an easing of New England's dependence on forejgn oil.

- action by New England states to urge greater equity in

the distribution of enerry costs nationally.

- increased oil support capacity in New England to handle offshore oil if and when it is discovered.

FEIERAL REGULATIONS ANJ) SMALL BUSINUSS

There is a need for:

- a state operated assistance program to aid firms in finding cost effective means of meeting federal standards.

UNEMPLOYMENT COMPENSATION TAX

There is a need to:

- restore solvency to the Rhode Island jobless fund through state imposed taxes, at reasonable leve1s, on business.

- ensure that benefits from the fund do not bankrupt it agrain by tightening eligibility requirements, particularly those for retirees.

UNSK ILLED LABOR

There is a need for:

- continued and renewed efforts to upgrade the labor force in Rhode Island.

FACILITIES

TOURISM

There is a need for: 
TOURISI (continued)

- construction of a convention center and/or rosort facility, by private investment, to attract and accomodate tourists.

- an intonsive publicity campaign to advertise the merits of Rhode Island as a vacation center. COMMERCIAL FISHING

There is a need for:

- continued state and local assistance to fishermen in obtaining and keeping dock space.

- expanded onshore support facilities to "capture" more of the indirect cconomic activity generated by commercial fishing.

\section{IMAGE}

There is a need for:

- intensive publicizing of Rhode Island's numerous attributes both inside and outside the state. GOVERNALNT LINITITIONS

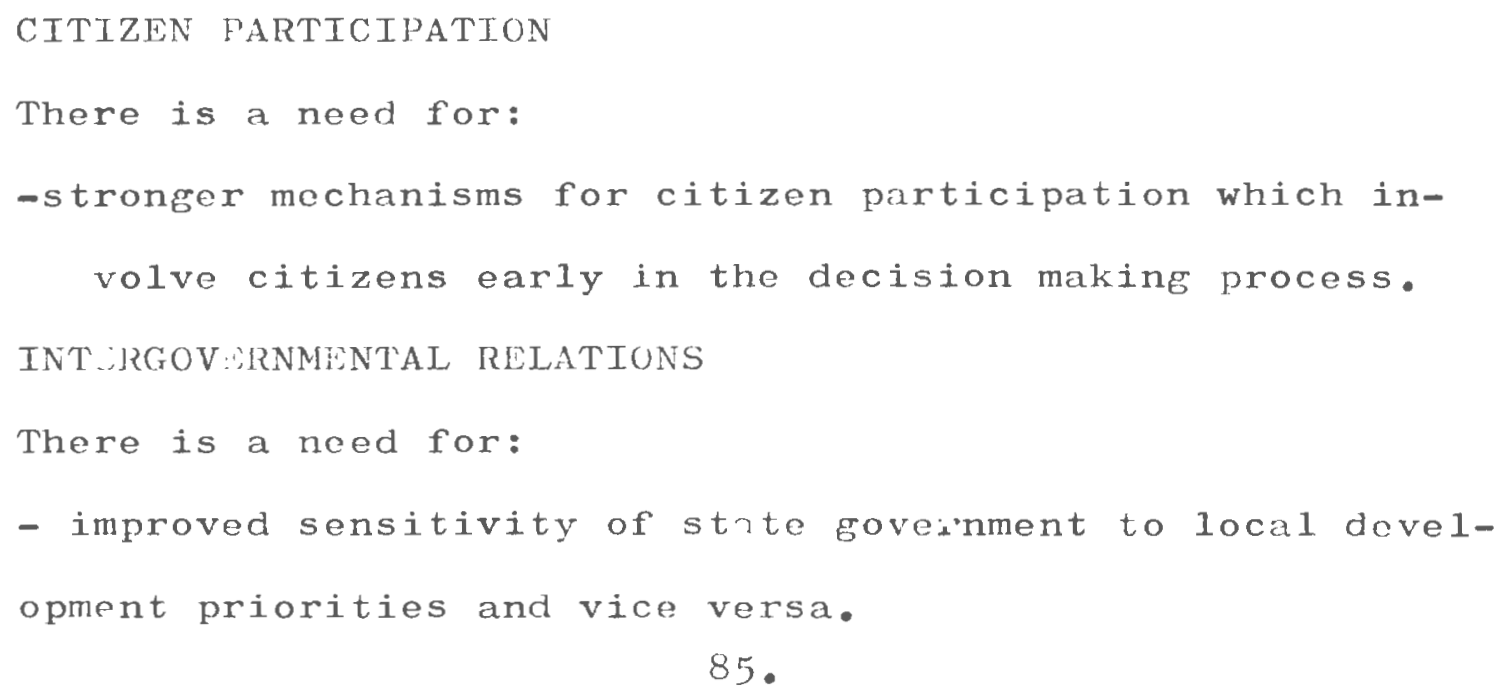


GOVLRNOR'S TERM OF OFFICE

There is a need to:

- extend the torm of office of the Governor to four years.

- inform the public of the weaknesses inherent in a two year term. 
${ }^{1}$ Harbridge House, Inc. Industrial and Commercial Varketability of Surplus properties in Rhode Island, Ipril 1976 p. II -23

2 Ibid p. IX -4

${ }^{3}$ Rhode Island Department of Liconomic Uevelopment, Rhode Island Basic Economic Statistics-The Economy summary and Trends, (1'rovidence 1978), p. 43

${ }^{4}$ Rhode Island statewide P'lanning Program, Rhode Island State Rail p1an, Report 31 , sug. 1977 p. 01.1

${ }^{5}$ Christopher Scanlon "Threat of cutback in railroad Service spells bnd news for R.I. commuters" The Providence Journal, hov. 12, 1978

6 Harbridge House, Inc. op. cit, p. I-7

7 Rhode Island Department of Economic Development, op. cit, p. 123

8 Hamilton Allen "Green Loses Millions to Logan" Providence Lvoning Bulletin, April 10, $1979 \mathrm{p} .1$

$9^{\text {Ibid }}$

$10_{\text {Rhode }}$ Island Department of Economic Development, op. cit, p. 129

${ }^{11}$ Rhode Island Statewide Planning Program, Toward A Comprehensive Economic Development Strategy for Rhode Island, Report \$33 Dec. 1977 DRAFT p. 2-3.14

${ }^{12}$ Rhode Island Statewide Planning T'rogram, plan for the Development and Use of Public Water Supplies, Report \#10 sept. 1969 p.23

13 Save the Bay, WEAX Radio, April 8, 1979

$1{ }^{4}$ Rhode Island Statewide Planning Program, Rhode Island Areavide water Uality Management Plan, DRAFT COPY

15 icademy for Contemporary Problems, Revitalizing the Northeastern Economy, Nov. 1977, p. 13 
16 Joseph L. Goodrich, "Will small business be out of business by the year 2000?" The Jrovidence Journal, Nov 12, 1978 , p. f -2

17 op.cit, $: 14, p \cdot 22$

18 Rhode Island Public Lxpenditure Council, Taxes on Business in 1976: Rhode lsland Compared to 11 Competitor States, Apri1 1977, p. 7

19 Joseph L. Goodrich, "Court striker pay ruling doesn't take R.I. off the hook" The Providence Journal, April, $1,1979, p . f-2$

20 op.cit, \#11 p. 01-05.1

${ }^{21}$ Grass-Roots, (Providence), October 1, 1977, p. 1

$22 \mathrm{Hsi} \mathrm{C} . \mathrm{Li}$ and Joseph 1. Ilacqua, "Economic and Psychological Costs of Unemployment Compensation Benefits for Strikers to Potential Investors in Rhode Island" (Mimeo) Nov. 4, 1977 p. 26

23 Providence Evening Bulletin, March 21, 1979 p. C-7

24 Ibid

25 op. cit, \#1

26 op.cit, \#11 p. O2-3.14

27 op.cit, \#18

28 Vincent Calitri, R.I. Department of Employment Security, telephone interview Tuesday, November 14, 1978

${ }^{29}$ Marcia Feld and Josephine F. Milburn, Workshops on Citizen Participation in Rhode Island, Aug, 1976 p. 10

$30 \mathrm{~J} . \mathrm{A}$. Schlesinger, "The Politics of the Executive" in Herbert Jacob and K.N. Vines, Edts, Politics in the American states (Boston, Litt1e, Brown \& Co., 1965) p. 219 


\begin{abstract}
In examining the summary needs assessment on the preceding pages one might consider the listings in either of two ways. They might be considered needs which must be fulfilled or they can be viowed as tasks which need to be accomplished. In some cases, programs or projects directed towards fulfilling these needs, or accomplishing these tasks, are already underway. In others, such programs or projects are still in the planning stage. Some of the listings, such as compiling an inventory of industrial land for example, lend themselves quite readily to implementation. Others, such as finding alternatives to petroleum as an energy source, are much more ominous tasks which will not be easily accomplished. In order to formulate economic develoiment policy however, the relative importance of needs or tasks, and some strategies for implementation, must be consiclered.
\end{abstract}

PRIORITIES

Vicwing the 1 istings as tasks permits classification in two major categories, defensive tasks, which are tasks which must be undertaken to overcome specific limitations on the state economy, and aggressive tasks, or tasks which will lead to improver utilization of the state's resources. 
These tasks can be further broken down into those which require immediate attention or will yield immediate benefits and those which will require attention over the long term or will yield long term benefits. Thus we have four categories of tasks, defensivn short term, defensive long term, and aggressive short and long term tasks. I possible arrangement of priorities can be establishod on this basis.

First priority should go to defensive projects to alleviate those factors which represent the most serious limiting factors to economic develonment. These include tasks 1 isted under sowers, energy, unemployment componsation, air service and federal regulations and small business. $\$ 11$ of these constitute projects of urgent necessity to cope with threatening crises. Second priority should go to aggressive projects and programs which will yield immediate benefits for Rhode Island's economy. These include construction of a major east-west highway in the state, an improved connection between routes 146 and I-90, completing and computerizing an inventory of industrial land, obtaining state control of surplus federal lands, improvements to facilities, and conducting publicity campaigns as mentioned under the headings of water supply, Governor's term of offico, and image. Each of these, if accomplished, will provide immediate benefits to Rhode Island's economy or provide the necessary 
ground work for third priority tasks.

Third priority should be assigned to aggressive tasks which will help provide long term benefits for economic development. These include establishing a statewide land management policy, drcdging in the 'ort of l'rovidence, improving the water sup ly, preparing nev industrial sites, and extending the torm of office of the Governor.

Fourth priority should go to defensive measures designed to eliminate minor barriers to economic development. These include replacing the Jamestown bridge, improving secondary roads and sign systoms, and programs to preserve Rhode Island's rail system. None of these projects are especially urgent, but all are important in assuring continued growth and develoment.

Three of the needs mentioned in the needs assessment have not been mentioned in this arrangement of priorities. These include upgrading the labor force, improving citizen participation and improving intergovernmental relations. These aro not tasks which can be readily undertaken and completed. Instead they are processes which are currently in progress and must bo continually pursued throughout the near future. Because of this they do not fit within the priority structure as arranged here but thoy are nonetheless important as an integral part of economic development in Rhode Is land.

In general then, efforts to develop the economy of 
Rhode Island should focus first on efforts to overcome the state's limitations and then berin to dral with cfforts to improve upon the state's assets. Hecause of the growing, labor force in Rhode Island, job creation must be a central theme of oconomic develoment but emphasis should also be placed on reducing the state's dependence on manufacturing and decreasing dependence on individual industries.

For example, the state's current dependence on the jewelry industry sets the stage for a possible crash should the nature of the international costume jewelry market change. By the same token, the increasing emphasis on the Electric Boat operation at Quonset threatens to make the state overly dependant on federal subnarine construction programs in much the same way that Seattle, Washington is dependant on aircraft or betroit is dependant on automobiles. This is not to say that development in jewelry and boat building should not be encouraged, certainly these jobs are needed, it is only to serve as a warning against overdependence on too small an economic base. In economic development efforts it should be kept in mind that diversity improves economic stability. Only diversification can protect Rhode Island from oconomic crashes such as those experienced in the past.

More emphasis should be placed on developing the state's greatest natural economic asset, Narraransett Bay. 
This can be in the form of cncouraging growth in tourism, fishing, and aquaculture, and oil support services. At the same time, it is important to proserve the guality of lifo which also scrves as one of the state's freatest assets.

STRATUGIES FOR INYLINENTATION

Completion of development tasks will require the cooperation of many different agencies of state, 1ocal, and federal government. To ensure that individual tasks are porformed, one agency, and preferrably one individual within each agency, i.e. the agency director, should be assigncd responsibility for overseeing and assuring complotion of cach task.

The Governor must be the driving force behind economic development efforts in the state. Primary responsibility for the administration of most tasks must lie with the office of the Governor. The executive is the only individual in the state with the power to regulate the various line agencies which must cooperate to ensure successful implementation. Therefore the Governor should assign responsibility among these agencies to onsure implementation.

Obvious1y there are cxceptions to this rule. The Governor does not control the logislature or tho governments of individual citios and towns. Obviously projects which 
require action on the part of these governmental bodies cannot be undertaken by the Governor. For example, the Governor's Office cannot be rosnonsible for adopting a stateride land manasement policy. This can only be accomplished by logislative action. By the same token, extension of the Governor's term of office cannot bo brought about by exccutive action. Other areas where exccutivo action is not a feasiblo means of implementation are indicated as they aro discussed below.

Although the Governor should have rosponsibility for the administration of most of the development tasks discussed, responsibility for actual implomentation must lie with specific stato, local and fedoral agencies. A functional strategy for implementation involves the assignment of responsibility to specific agencies by the administration. Projects can then be coordinated and carried out by the principal agoncy in charge. An indication of some of the agencies with which responsibility should lie follows.

SEWLRS

Responsibility for upgrading sewer systems lies with individual cities and towns. Ilowever, the Statewide lanning probram is preparing the lreawide water luality lanagement Plan, a "208" Plan, for the State of Rhode Island and the Department of ienvironmental Management's Rogulation 
Scction, Division of hater Resources is responsible for oversecing implomentation. Since waste water does not respect town boundaries the problem must be considered a state problem and therefore responsibility must lie with tho lattor arency. Of course significant funding must come from the federal Environmental l'rotection Agency.

ENERGY

The Governor's energy office should be given responsibility, in coordination with the statewide Planning Program, for drafting a State Energy lian. This plan should be designed to include active state programs to reduce dependence on petroleum products for energy and to provide state incentives for alternative energy development. In addition, it should contain contingency plans to help assure Rhore Island's economic survival should political strife in oil exporting nations intorrupt Rhodo Island's petroleum supplies. Certain parts of this vian could be adopted by the legislature as a statewide knergy policy.

\section{UNEMILOYMENT CQNIENSATION}

The unemployment compensation issuc is a very difficult one. Because of the political implications involved in the labor/management conflict over unemplorment compensation, there is great reluctance to even discuss the matter in state government. Nonetheless the problem must be 


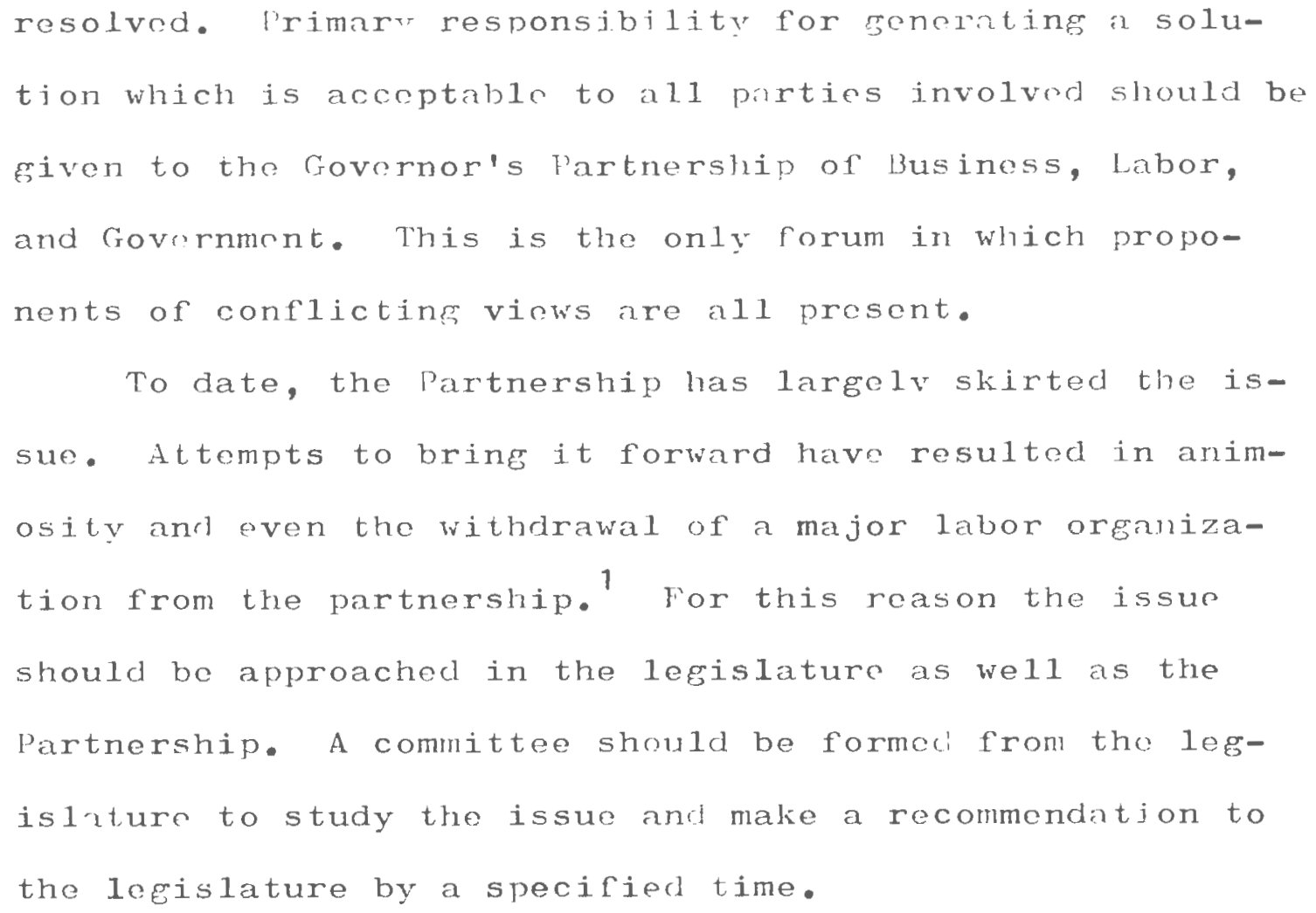

ATR SERVICE

Tnjorovements to Green Airport are the responsibility of the Department of Transportation, Iivision of Airports. Coordination with the Federal Aviation Idministration is of course important, and the Deprrtment of Liconomic Vevelonment might assist in efforts to attract now air carriers after renovation of the facility is complete.

FEULRAL REGLLATINS AND SMALI BLSIIESS

In order for the 5 tate of Rhode Island to properly tend to the neods of small business and encrurage the growth of small business in the state, a new division of

$$
96 .
$$


the Uepartment of liconomic levelopment should be formed. This division, the Jivision of small Business levelopment, would deal exclusively with the problems of small business. It would be rosponsible for assisting small. buininess in finding economical ways of conforming to federal regulations and could provide technical assistanco to these firms in handling their unique problems.

\section{ROADS AND BRTDGES}

Plans for the construction of a major east-west highway are already underway. These are the responsibility of the State Department of Transportation and must be carried out in cooperation with the Foderal IJighway Administration, a major source of funding.

Replacement of the Jamostown Bridge will require cooperation of the jepartment of Transportation Division of Publjc Works and the Rhode Tsland Turnpike and Bridge luthority. The Turnpike and Bridge Authority should be given authority to issue bonds for the new bridge much as was done for the Newport Bridge.

Improvements to secondary roads are the responsibility of individual cities and towns and can be accomplished with funding and other incentives from the state Depart... ment of Transportation's Uivision of Vaintcnance. Improvements to the linkage between routes 146 and I-90 must be undertaken by the state of Yassachusetts. To 
encourage this, the fovernor's lffice should berin negotiations with the Governor of the state of Massachusetts.

$L A \backslash D$

Continued negotiations with the fereral government for control of focleral lands must be carrica out by the Governor's Office in cooperation with the lepartment of Lconomic Develonment and the Rhode Island lort luthority.

The responsibility for updating and computerizing a statc-wide industrial land inventory should lie with the Statewide l'anning Jrogram. This file should be maintainod by, and accessible to, both the tatewide Planning program and the State Department of Economic Develoment.

\section{FICTLTTIES}

Construction of tourist facilities should be undertakon by private investment. Howevor the lepartment of liconomic Developmont's Vivision of Tourist l'romotion could undertake an active campaign to encourage such development. Improvoments to commercial fishing facilities are being undertaken by the Department of Environmental Management in the l'ort of Galilee and in Newport, Rhode Island. 2 Here again, howevor, every effort should be made to encourage private scctor investment in support facilities. 
IIITGE

\begin{abstract}
lublic rolations promrams to improve the state's imare both within and outside the st.te must be the responsibility of the Department of Economic ifvelopment.
\end{abstract}

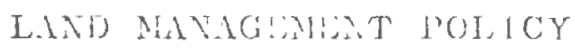

This is one of the projects which cannot bo administered by the Governor. The Governor has recently been attempting to get a land management bill through the legislature and has been unsuccessful. Responsibiliy for the passage of such a bill lies solely with the legislature but the Governor can improve its chances of passage by takins a more agrressive, leadership role and ensuring that all state agency administrators aro moving toward this same end.

In addition, the Statewide Planning Program might conduct an intensive campaign to inform Rhode Islanders of the need for, and advantages of, such a policy. Such a program should encourage individuals to inform thoir legislators of this need and help to generate citizen input promoting action in the legislature.

BAY SHL'T'JNG

Improvements to the Port of l'rovidence will require cooperation between the Rhode Island port iuthority, the 99. 
City of Providence, the City of last lrovidence, The Irmy Corps of Hnfineors, and the Fe'oral Environmental Protection igency. The l'ort luthority should assume the lead role and coordinate these othor agnncies.

\section{WATER IROJECTS}

Lnsurin; sufficient wator suply is the responsibility of individual cities and towns in cooperation tith the Statewide Panniner Propram's Plan for the Development and use of l'ublic liater supplies, The state lepartment of health, .)ivision of water supply and lollution Control, the Jublic Utilitics Commission and the State iator Resources Board.

One project is currently in the planning stage, the Big Rivor Reservoir. This resorvoir would be constructed by the Irmy Corps of Engineers. The State Water Resources Board should undertake an intensive public information campaign to explain the noed for this facility.

\section{RAILWAY PIRLSERVATTON}

This should be the responsibility of the state Department of Transportation and the statewide jlanning Program and can be accomplished largely with Fecieral Railway l'reservation Funds. 


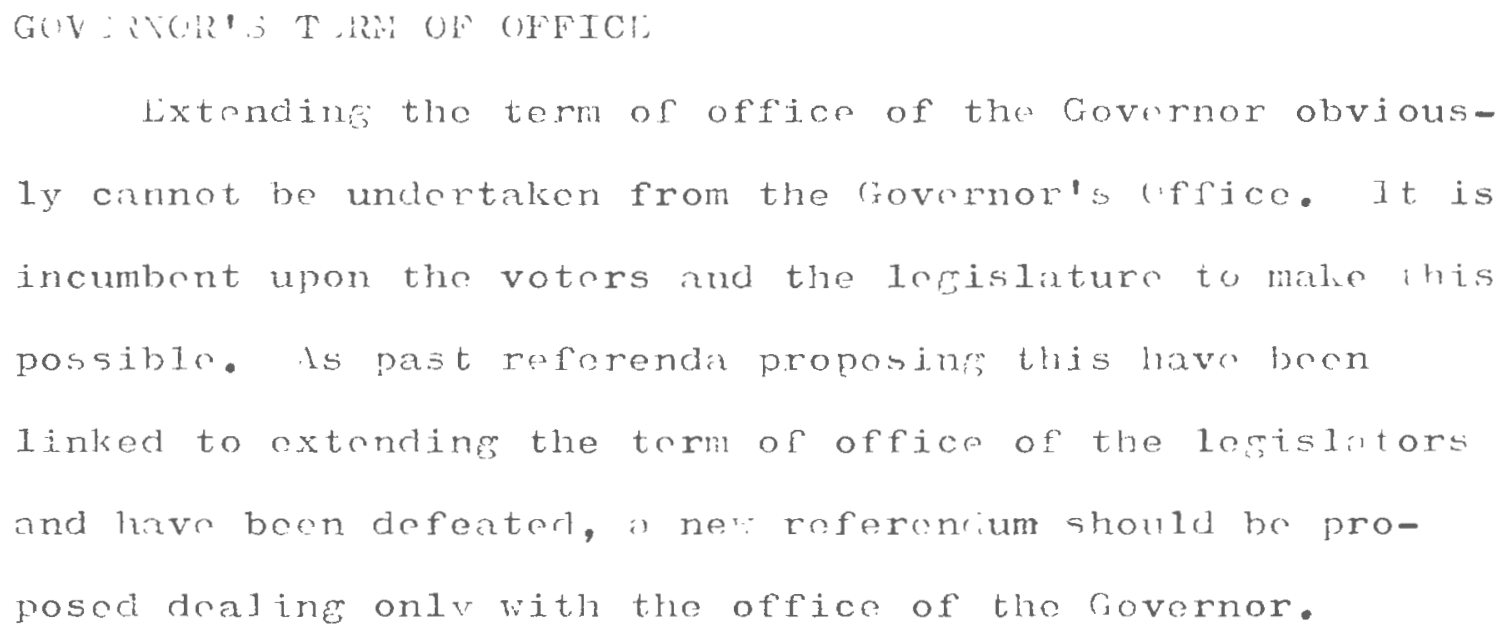




$$
\text { A T B. }
$$

The following is a list by categories of agneies and orfanizations that have or potentially have a simnificant and direct afrect on econonic devoloment in Rhode lsland. This 1 ist was prepared by the statewide 'lanning program for publication in state Guide. Lan lilement 211 , Report Number 33, Toward a Com rehensive iconomic Dovoloment Strategy for Rhode Island.

The list is classified in relationship to employment. There is ovorlap in cascs where an agency functions in several was with respect to employment. Each agency/organizatjon is identified as one of the following:

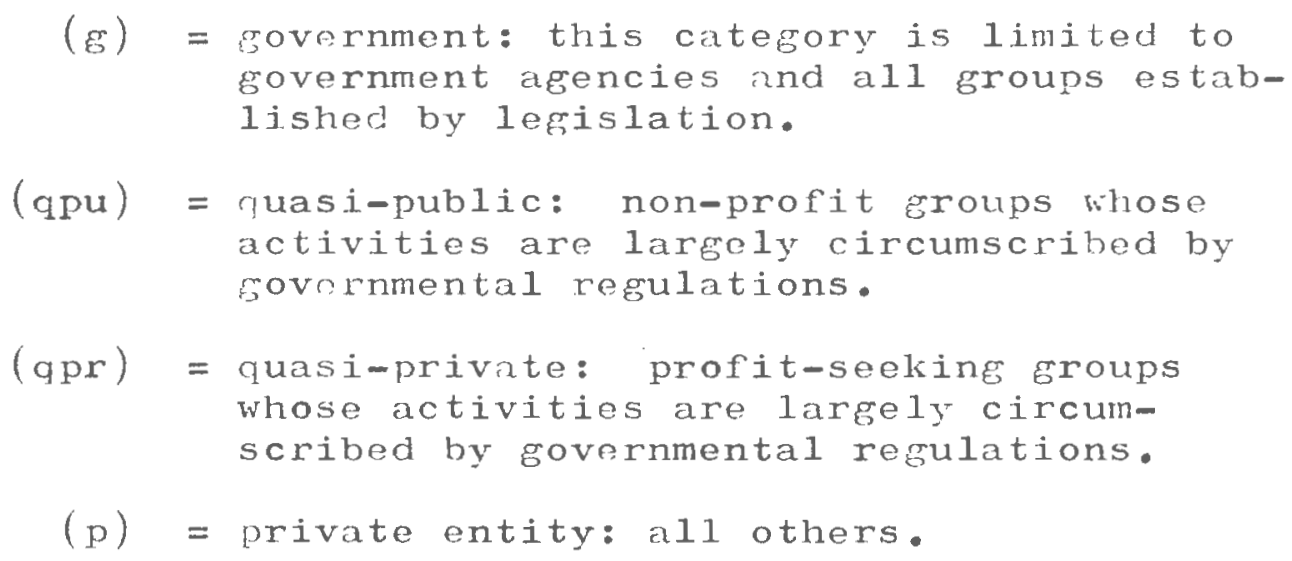


Those who orovide fobs:

Private firrs - approximately 24,000 (p)

Federal governent - CETA $(g)$

State and local zovernments $(\xi)$

Hon-profit agencies, including hospitals ( $q p u$ )

Those who hold or seek jots:

R.I. Labor Eorce (1975 estimate, 426,000) (p)

Those who train job seekers:

R.I. Department of Economic Development, Job Development and Training Division

WIII progran (z)

SRS - Vocational Renabilitation Services Division ( $g$ )

Dept. of Education - Vocational Education Bureau $(\varepsilon)$

Rhode Islanc College (g)

Rhode Island Jurion College (g)

Salve Pejina Colleze (qpu)

Providence Collese (qpu)

University of Plogde Island $(g)$

Erovin Universit $(g, 0 u)$

Bryant CoIlsos (avi)

Joinson ?: $\because z$ les (apr)

Lo local school s $\because$ siems $(g)$

private bisiress jaaining programs ( $\left(D^{\prime}\right)$

sheltered er:-0:- :-:5 agencies (opu)

OIC (OSL)

City oî Eroviterz E Erime Sponsor (g)

Specialfzed train:ns schools (nursing; mechanics, secretariミ1, co-nputer, etc.) (qpu; qpr; p)

Thuse who nozasse-i job providers/job holders

Rhode Islari Euiders Association (p)

Rhode Islan: Earoleum Association ( 0$)$

Rhode Island AZ-CIO (qpr)

other unicns ens business associations (qpr and p)

Those who proyse job information:

Rhode Island Jepartinent of Employment Security (६)

Opportuntifes for bomen (opu)

Departient of Community Afrairs - Division on Youth (E)

Dept.of A.cine (E)

Rhode Island College ( $g$ )

Providence Joumnal-Bulletin ( $(0)$

U.S. Depantnen: of Labor--Veterans Employment Services ( $g$ )

State Occupationaz Information Comittee (g)

Dept. of Economic Development (g)

Private emoloyment agencies (o)

appendix-2 
Those tho finance job provicers:

Phode Island Development Council $(g)$

Industrial Building Authority ( 5$)$

Recreational Building Authority ( $g$ )

Rhode Island Fousing \& Hortgage Finance Corp. (s)

28 local development agencies (r)

Phode Island Banks (opr)

Small Business Administration ( $g$ )

Business Developrent Coro. (apr)

Narragansett Development (gor)

Business opportunities (opr)

Those tho finance job seekers:

WIN program ( $\mathrm{g}$ ) (SRS)

Dept. of Employment Security - unemployment compensation (g)

Dept. of Economic Development - Ocean State Training School (s \& p)

Those uho seek ¿o attract job providers:

Department of Economic Development $(g)$

R.I. Public Experciitures Council (opr)

R.I. Chamber of Com-erce (p)

Local Chamber of Commerce (D)

:ew England Se

Governor's office ( $\overrightarrow{5})$

General Assembiy ( 5$)$

Howard Developmen: Jopporation $(g)$

Aoulanec'k Develop-ant Corporation ( $g$ )

Burrillvilie Seviosment Corporation ( 5 )

Those who rezulate iob providers:

Coastal lesounces Vanagenent Council ( 8 )

Dept. of Elisiness Pegulation (E)

Health Departrent ( 5 )

Publia Utilities Commission ( $g$ )

Dept. of Iabor ( $\tilde{s})$

General Assenoly (5)

Dept. of l:atural esources ( 5 )

Water Resources Boand ( $g$ )

Attorney General (g)

Consumer's Council (g)

Enercy office ( $s)$

Those whose planning activities attempt to directly affect job trainirf and developrent:

Dept. of Econcmic Sevelooment ( $R$ )

Dept. of Administration - SPP - Budget Orfice (E)

Covernor's Office $(\tilde{z})$

Dept. of Fransporzazion ( $z$ )

AlipBs (Arez Yanoo::er Planning Boaràs) (g)

SfisC (State lanpo:? Services Council)(

appendix -3 
Those vhose planning activities attemot to directly affect joj training and development: (cont'd)

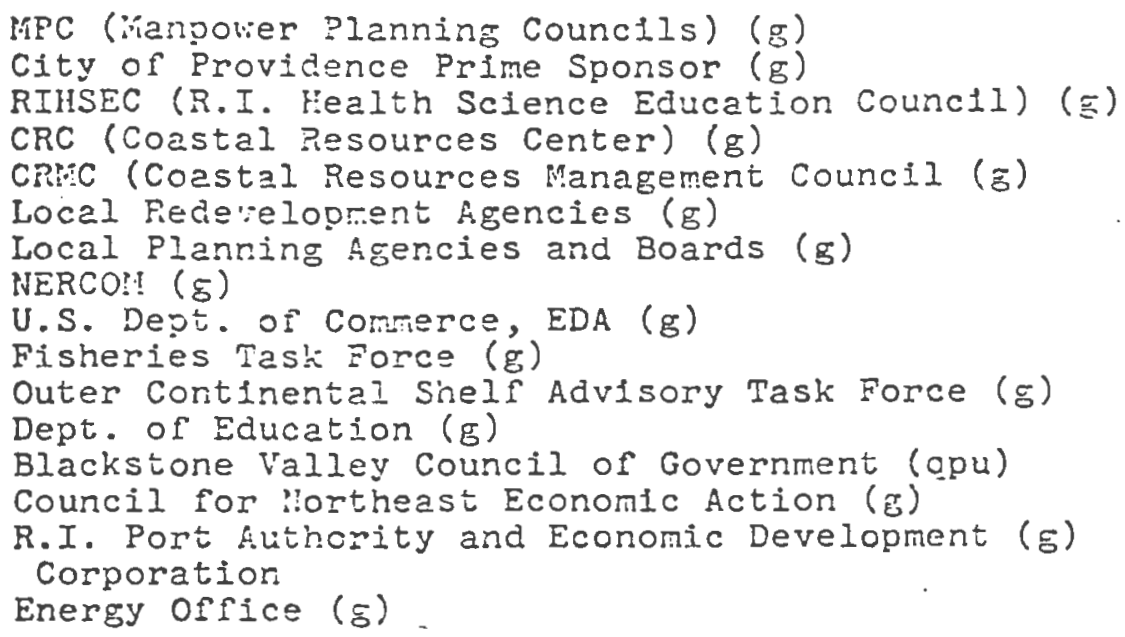


dcademy for Contemporary lroblems. Revitalizing the Northeastern Economy. Acaremy for Contemporary lroblems. iasilington. 1977

Mllen, IIamilton. "Green Loses "ilitons to Lofan". Jrovidence livening Bulletin. Ipri1 10, 1979

Bakst, 1. Charles. "llmond has plan to aitract firms; Garrahy his a firm" The : rovidence Journal. sept. 8 , $19 \div 8$

Calitri, Vincrnt. R.I. Department of Lìployment security Telephone interview. Tuesday, Vovember 14, 1978

DeRoos, Robert. "ihode Island, New England's I.ively Experiment". Nat'1 Geographic Nagazime. Sept.,1968

Feld, Marcia $1 /$ and Milburn, Josephine F. Workshops on Citizen l'articipation in Rhode Island. Providence. Rhordo Island Committee for the Humanities. 1976

Goldstein, Gerald S. "R.I. Plans $\$ 2.5$ million to derelop fishing port" The Irovidence Journal, March 22, 1979

Goodrich, Joseph L. "Will small business be out of Business by the year 2000?" The Providence Journa1, November 12,1978

- "Low New ingland Wai"es Seen Attracting Business" Providence Evening Bulletin. November 10, 1978

Crass-Roots. Providence. October 1, 1977

Hawbridge House Inc. Industrial and Commercial larketability of Surplus Properties in Rhode Island. Boston. Harbridge House Inc. 1976

IIsi C. Li and Ilacqua, Joseph A. "Economic and P'sychological Costs of Unemployment Compensation Benefits for strikers to Potential Investors in Rhode Island". Yimeographed. November 4, 1977

The New York Times. Nay 25, 1977

Parisi, Anthony J. "l rofits from the Sun". The New York Times. Sunday April 3n, 1978

Providence Evening Bulletin. "Fiat Selects Providence l'ort; 10, 000 Cars Due Annual1y" March 14, 1979 
Providence livening Bulletin. March 21, 1979

Reid, Dave. "Stcelworkers to ignorr Covernor's Partnershi " The Providence rvening Bulletin. Oct. 17, 197 is

Rhode Island Department of Fcononic beveloymont, Rhode Island. n.d. n. D.

- Rhode Island Basic liconomic statistics-The Liconomy, summary and Trends. I'rovidenco. 1978

- "Rhode Island: Its opportunities Can't be Neasured in square Miles". Forbes. Vhy 1., 197.

Rhode Jsland l'ublic Expenditure Council. Taxns on Businoss in 1976: Rlode Island Compared to 11 Competitor

Statos. I'rovidenco. 1977

Rhode Island statewide I'lanning 'rogram. Job Neod in Rhode Is land, Estimatine the umber of Jobs Necded 19701985. Technicil Paper iumber 7?. June, 1978

- Rhode Island Overal1 Liconomic Develonment Program. Providence. 1978

- Plan for the Development and Use of Public liater Supplies. Report Number 10. Sept., 1969

- Rhode Island Ireawide Water (uality Management IIan. DRAFT COJY. Sept., 1978

- Rhode Island state Rail Plan. Report Number 31 iugust, 1977

- Rhode Island Transportation Plan - 1990. Report urnber 19. 1973

- State Land Use Policies and jlan. Report Number 22. January, 1975

- Toward A Comprehensive Economic Development Strategy for Rhode Island. Report Number 33. IDRIFT Cu'Y. Decembor, 1977

Save the Bay. WEll Radio. April 8, 1979

Scanlon, Christopher. "Threat of cutback in railroad service spells barl news for R.T. commuters" The I'rovidence Journal. Nov. 12, 1978

schlosinger, J.A. "The "olitics of the Executive" in Herbert Jacob and K.N. Vines, Edts. Politics in the Imerican rates. Boston. Little, Brown e. Co. 1965 
United States Department of Commerce, Bureau of the Census. Area Measurement Reports. GE20, No.41, Apri1, 1967

- Characteristics of the Population, Vol. 1, Part 41, Rhode Is land. 1970

- Current Population Reports, Population Estimates and Projections. Series P-25. No. 778. Jan., 1979

United States Department of Commerce, N.O.A.A.. State of Rhode Island Coastal Management Program and Final Environmental Impact Statement. March, 1978

University of Rhode Island. Rhode Island Resources. Vo1 24 No. 2. $\operatorname{Ta11}, 1977$

Walton, Steven. "Location Dynamics and the Jewelry Industry in Rhode Island" Mimeographed. 1977 